\title{
Geochemistry and petrology of high-pressure kyanite-garnet- albite-K-feldspar felsic gneisses and granulites from the Kutná Hora Complex, Bohemian Massif
}

\author{
Stanislav VRÁNA*, Veronika ŠTĚDRÁ, Radmila NAHODILOVÁ \\ Czech Geological Survey, Klárov 3, 11821 Prague 1, Czech Republic; stanislav.vrana@geology.cz \\ * Corresponding author
}

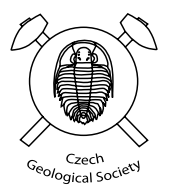

The Kutná Hora Complex (KHC), bordering the Moldanubian Zone at the north, represents a crustal stack of several allochthonous units. This study presents new interpretation based on detailed whole-rock geochemical analyses, petrology, mineral analyses and geothermobarometric calculations. Samples were selected from the Malín and the Běstvina units, with preference for kyanite-bearing albitic felsic gneisses with high-pressure metamorphic record.

Three types of kyanite-garnet-albite-K-feldspar rocks studied include: (1) an early Variscan felsic granulite from the Běstvina Unit equilibrated under eclogite-facies conditions $\left(\mathrm{P}=1.8-2.1 \mathrm{GPa}\right.$, metamorphic event $\left.\mathrm{M}_{1}\right)$, (2) a garnetkyanite leucosome from a polymetamorphic migmatite ( $\mathrm{P} \sim 1.6 \mathrm{GPa}$, metamorphic event $\mathrm{M}_{2}$ ), and (3) a felsic kyanite-garnet-muscovite gneiss derived from garnetiferous leucogranite, equilibrated under amphibolite-facies conditions $\left(\mathrm{P}=\right.$ 0.9-1.1 GPa, metamorphic event $\left.\mathrm{M}_{3}\right)$. All the three rock types exhibit geochemical characteristics of highly evolved leucogranitic rocks with low $\mathrm{Zr} / \mathrm{Hf}$ ratios (14 to 19), relatively low FeOt/MnO (10 to 33), and contain $<30 \mathrm{ppm} \mathrm{Zr}$, $<15 \mathrm{ppm}$ Y, and low $\Sigma$ REE $(<28 \mathrm{ppm})$ abundances. The kyanite-garnet-muscovite felsic gneiss contains locally garnet porphyroclasts up to $3 \mathrm{~cm}$ in diameter, with up to $28 \mathrm{~mol}$. \% spessartine and $0.55 \mathrm{wt} \% \mathrm{P}_{2} \mathrm{O}_{5}$, which represent relics from the magmatic stage of the garnetiferous leucogranite precursor. Accessory tourmaline (dravite-schorl) and dumortierite occur in migmatitic gneisses of the Malín Unit, while dumortierite is common in the felsic gneiss $\left(\mathrm{M}_{3}\right)$. Textural relationships indicate a late, post-kinematic growth of tourmaline and dumortierite in relation to $\mathrm{D}_{3} / \mathrm{M}_{3}$.

The repetitive high-pressure record manifested during three metamorphic events in the Kutná Hora Complex represents a unique example in the Bohemian Massif. These relations indicate a separate evolution of the Kutná Hora Complex and the Moldanubian Zone during much of their Variscan tectonometamorphic history. Several aspects of possible correlation among the Kutná Hora Complex (plus the Svratka Unit) and the Orlice-Sněžník Unit at the Czech-Polish border, which all have a record of Palaeo-Variscan (U)HP evolution, are discussed.

Keywords: felsic gneiss, felsic granulite, leucogranite precursors, high-pressure metamorphism, polymetamorphism, Kutná Hora Complex

Received: 12 March 2009; accepted: 12 June 2009; handling editor: J. Kotková

The online version of this article (http://dx.doi.org/10.3190/jgeosci.045) contains supplementary electronic material.

\section{Introduction}

O’Brien and Rötzler (2003, tab. 1) and Janoušek et al. (2006a, tab. 8) pointed out the strong contrasts in PTt histories among the individual Variscan granulite bodies of the Bohemian Massif. Geochemical evidence shows that the most widespread felsic kyanite-garnet granulites of leucogranite-granite composition were dominantly derived from Lower Palaeozoic calc-alkali magmatic rocks (Janoušek et al. 2004). Nonetheless, other compositional types of granulites, such as highly differentiated rocks, are also of interest since they carry information, which is not revealed by studying the most widespread calc-alkali granulite types (Vrána 1989; Janoušek et al. 2006a, 2007; Kotková 2007; this study).

The Kutná Hora Complex (KHC), situated between the internal high-grade Variscan Moldanubian Zone and the structurally overlying low-grade (mainly Neoproterozoic) Bohemicum Zone, contains some of these interesting granulite and felsic gneiss types. The aim of our study is to constrain the metamorphic history of the KHC, focussing especially on its contrasting features in comparison with metamorphic patterns characteristic of the neighbouring parts of the Moldanubian Zone as qualitatively indicated by data presented for KHC by Synek and Oliveriová (1993), Owen and Dostal (1996) and Tajčmanová et al. (2006) for the NE part of the Moldanubian Zone. The main methods of study were detailed whole-rock geochemical characteristics including trace elements, together with petrology and mineral chemistry used for geothermobarometric interpretation.

The studied samples include kyanite-garnet-muscovite-albite-K-feldspar felsic gneisses from the Malín Unit (Figs 1-2). A kyanite-garnet-albite-K-feldspar 


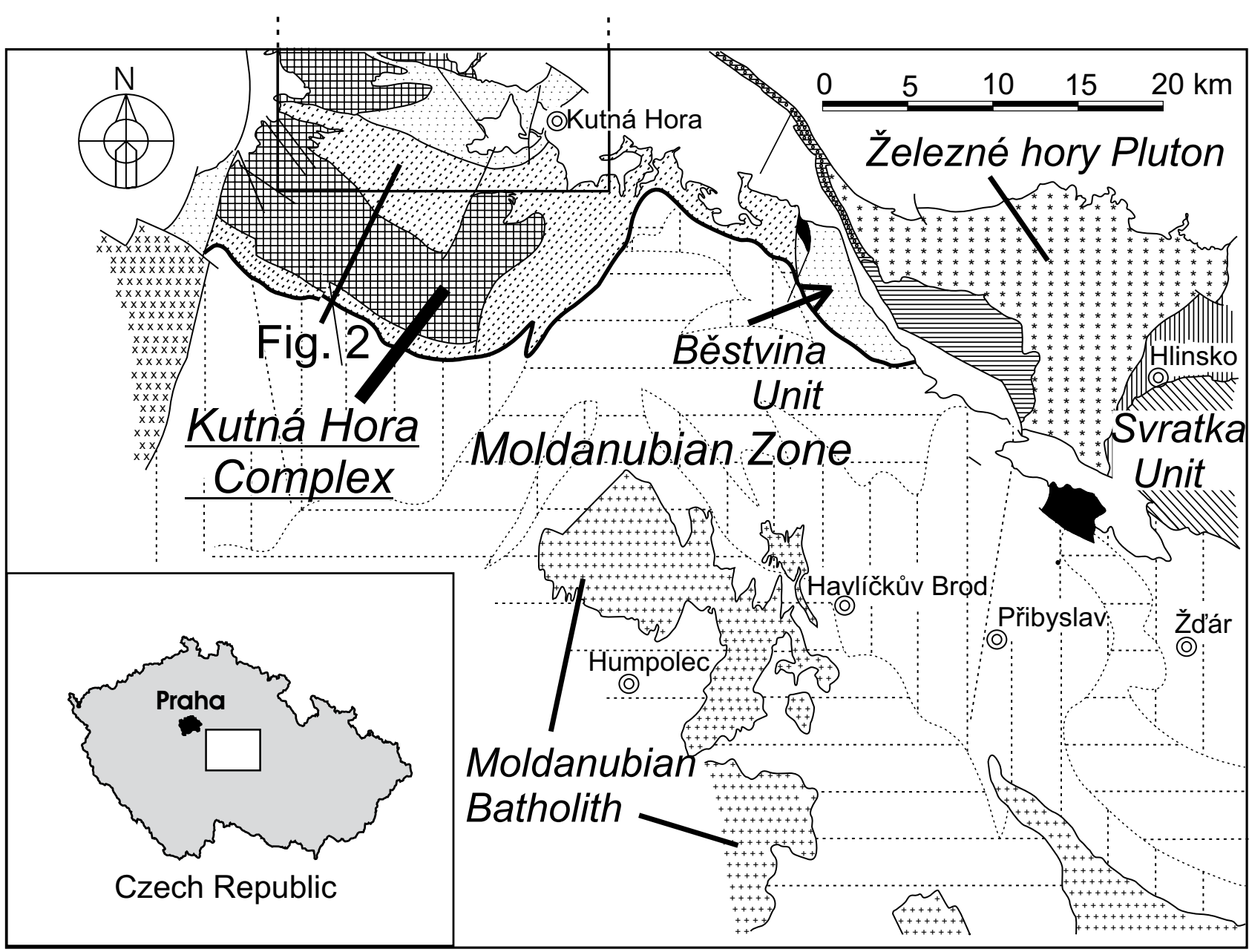

\begin{tabular}{|c|c|}
\hline & $\begin{array}{l}\text { Permian-Cretaceous } \\
\text { sedimentary cover }\end{array}$ \\
\hline 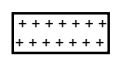 & Moldanubian Pluton \\
\hline 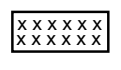 & Central Bohemian Pluton \\
\hline 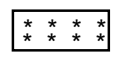 & Železné hory Pluton \\
\hline 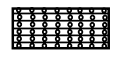 & Podhořany Unit \\
\hline 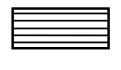 & Oheb Unit \\
\hline 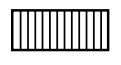 & Hlinsko Unit \\
\hline
\end{tabular}

\section{Kutná Hora Complex:}

Mica Schist Unit

Kouřim Unit

\begin{tabular}{|c|c|}
\hline$\ldots$ & Malín and Běstvina units \\
\hline & Svratka Unit \\
\hline & Varied Unit of Moldanubicum \\
\hline & Monotonous Unit of Moldanubicum \\
\hline & Large ultramafic bodies \\
\hline
\end{tabular}

Fig. 1 Geological setting of the studied area in the Kutná Hora Complex, modified after Synek and Oliveriová (1993).

leucosome from polymetamorphic migmatite in the same unit is also included for comparison. The Běstvina Unit is dominated by felsic granulites of calc-alkali leucogranite and granite composition, but samples 5 and 6 from the set studied by Vrána et al. (2005) are albite-K-feldspar felsic granulites equilibrated under eclogite-facies conditions.
The felsic gneisses from the Malín Unit and the albite granulite from the Běstvina Unit are compared with calcalkali kyanite-garnet granulites of granitic composition and biotite-kyanite-garnet granulite (of Fe-rich paragneiss composition) from the Běstvina Unit. The aim is to show the differences in the whole-rock geochemistry 

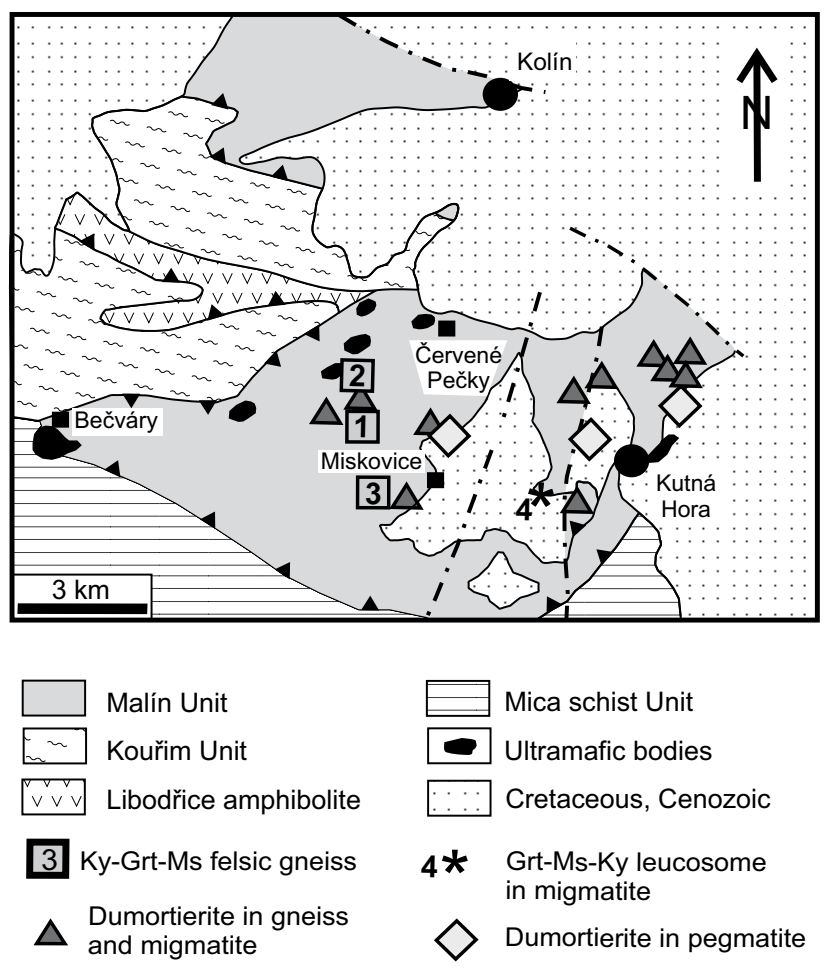

Fig. 2 Location of the studied samples (Nos 1 to 4 ) and dumortierite localities near Kutná Hora. Dumortierite localities after Losert (1956a), geology modified after Synek and Oliveriová (1993). Symbols for the individual samples overlap the location of villages and other places mentioned in text as local names (Tab. 1). Please refer to the online map at http://dx.doi.org/10.3190/jgeosci.045.

(protolith composition) and in the metamorphic record among samples from the Kutná Hora Complex.

Attention is paid to accessory tourmaline and dumortierite, present both in the felsic gneisses and in the polymetamorphic leucosome. This information will be important for understanding the timing and conditions of emplacement of the dumortierite pegmatites (Cempírek and Novák 2006) in the KHC in relation to the general sequence of events in this unit.

When dealing with metamorphosed igneous rocks, it is often useful to refer to the terminology of the corresponding magmatic rocks. The reason for accurate discrimination of the various felsic rock types are the occurrences of garnetiferous hyperpotassic syenitic alkali-feldspar granulites and alkali-feldspar (granitic) granulites in southern Bohemia (Vrána 1989), and the fact that this study deals with some geochemically highly evolved rock types.

According to the IUGS classification of igneous rocks (Le Maitre 1989), a compositional limit of An $<5$ mol. \% is set for inclusion of albitic plagioclase among alkali feldspars. This limiting value is significant in terminology, e.g. alkali-feldspar granite vs. granite ("normal", calc-alkali granite). Because many of the samples studied have plagioclase composition in the range of $\mathrm{An}_{2}$ to $\mathrm{An}_{9}$, we use the designation albite-K-feldspar granulite (or precursor granite), to avoid confusion.

\section{Geological setting}

The Kutná Hora Complex (KHC) is situated between the internal Variscan Moldanubian Zone and the structurally overlying low-grade (mainly Neoproterozoic) Bohemicum Zone (Fig. 1). The introductory information on regional geology and structure of the wider area is presented in the accompanying paper by Verner et al. (this volume). The uppermost part of the KHC is divided into three units:

1) Běstvina Unit (Losert 1967), built by felsic granulites and partly migmatized gneisses with lenses of garnet peridotites, eclogites, and rare garnet amphibolites; the unit which is 8 by $3 \mathrm{~km}$ in size, constitutes the southeastern segment of the Kutná Hora Complex (Fig. 1),

2) Malín Unit (Malín Formation of Losert 1956a, b) consisting mainly of leucocratic kyanite-bearing migmatites accompanied by garnet amphibolites, partly serpentinized garnet peridotites, eclogites and several skarn bodies,

3) Plaňany Unit (Fišera 1977) built by various types of migmatites (metasedimentary and metaigneous mafic) with lenses of amphibolites, serpentinites and pyroxenites; no samples from this unit were included in the present study; the small unit is located NW of the area shown in Fig. 2,

4) the underlying units represented by the Kouřim Unit consisting of orthogneiss with fine-grained leucocratic migmatites and by the lowermost Mica Schist Unit consisting of metapelites intercalated with amphibolites (Synek and Oliveriová 1993) (Fig. 2).

According to Synek and Oliveriová (1993), rocks of the Malín Unit were involved in several deformation (D)/ metamorphism (M) events: the $D_{1} / M_{1}$ event coincided with crystallization and emplacement of garnet peridotites/lherzolites (dated at $377 \pm 20 \mathrm{Ma}$, Brueckner et al. 1991), eclogitization of basic rocks and metamorphic crystallization of $\mathrm{HP} / \mathrm{HT}$ granulites. The $\mathrm{S}_{1}$ metamorphic foliation is generally subvertical or steeply dipping to the $\mathrm{NE}$, but rarely preserved in the Běstvina and Malín units (Nahodilová et al. 2005). The $\mathrm{D}_{2} / \mathrm{M}_{2}$ event is characterized as a mylonitization and retrogression event in HP eclogite/amphibolite-facies, reworking the older $\mathrm{S}_{1}$ fabrics into a flat penetrative $\mathrm{S}_{2}$ foliation dipping to the NW or NE. Accompanied was by a late-stage partial melting and migmatization generating kyanite-bearing leucosomes. The $\mathrm{D}_{3} / \mathrm{M}_{3}$ event produced $\mathrm{S}_{3}$ mylonitic axial cleavage and foliation with newly crystallized biotite and muscovite ( \pm garnet, kyanite) under HP amphibolite-facies conditions. 
Following the interpretation by Synek and Oliveriová (1993), the units comprising the Kutná Hora Complex represent a stack of allochthonous segments of crustal rocks with lenses of upper-mantle pyrope peridotite/ lherzolite up to $1 \mathrm{~km}$ long. The thrusting probably took place before the $\mathrm{D}_{3}$ event. Data on crustal eclogite and garnet peridotites in the Běstvina Unit were presented by Medaris et al. (2006) and Faryad (2009).

\section{Methodology}

\subsection{Samples}

The studied lithologies include three rock types representing parts of the Malín Unit and the Běstvina Unit. The criterion for sample selection was the modal presence of garnet, kyanite and albitic plagioclase. The samples were selected from a large sample set studied in connection with geological mapping of the Kutná Hora area on the scale of $1: 25000$ by one of the authors (Štědrá et al. 2009). In addition, we used several granulite samples from the Běstvina Unit characterised by Vrána et al. (2005).

The kyanite-garnet-muscovite felsic gneiss, exposed in abandoned quarries south of Bohounovice (sometimes referred to as the Bořetice locality - Fiala et al. 1982; Fiala 1992) and northeast of the village of Suchdol (Fig. 2), occurs as compositionally homogeneous layers up to $25 \mathrm{~m}$ thick. It is represented by samples 2 and 501 taken from the same outcrop. Sample 501 is identical with sample 2, except for the presence of widely scattered, large garnet porphyroclasts in the former sample.

The bodies extend along the strike of the country rock for a distance of several hundred metres, resembling an aplite sheet (Fiala 1992). The country rocks are represented by the migmatitic kyanite-garnet-muscovite paragneiss and the muscovite-biotite paragneiss of the Malín Unit (Synek and Oliveriová 1993). Fiala (1992) noted the presence of thin (several $\mathrm{cm}$ thick) sills and discordant dykes in the proximity of the main felsic gneiss body. Fiala et al. (1982) and Fiala (1992) wrote that the "felsic gneisses are of granulitic character (approx. $\mathrm{T}=$ $700{ }^{\circ} \mathrm{C}, \mathrm{P}=0.9 \mathrm{GPa}$ ), their genesis cannot be separated from gneissic surroundings, and it is therefore reasonable to suppose the HP granulite metamorphism for the Malín Unit ('Malín Formation') as a whole".

A garnet-muscovite-kyanite leucosome from the polymetamorphic migmatite in the Bylanka brook at outskirts of Kutná Hora (sample 4) was studied as an example of the Malín Unit migmatites.

The studied garnet-kyanite-albite-K-feldspar granulite (samples 5 and 6) from the Běstvina Unit is exposed on a $20 \mathrm{~m}$ high cliff in the Doubrava River valley c. $400 \mathrm{~m}$ west of the village of Spačice (Faryad 2009). Garnetkyanite granulites predominantly of calc-alkali granite (leucogranite) composition, (Fiala et al. 1987; Vrána et al. 2005), represent the main rock type of the Běstvina Unit (samples 7 and 8).

Although geochemical data for the Běstvina granulite samples were presented recently (Vrána et al. 2005), minor- and trace-element abundances were newly analyzed by more accurate methods, performed in the same laboratory as the trace-element analyses for the recently studied $\mathrm{Ab}-\mathrm{Kfs}$ rocks from the KHC. For comparison, new data from several granulite samples from the Běstvina Unit are included here.

Fiala et al. (1982) published a comparative mineralogical and major-element whole-rock geochemical study of kyanite-bearing felsic gneisses from the KHC, accompanied by several samples of granulites from the Běstvina Unit and from the Moldanubian Zone, all designated as "leptynites". The trace-element concentrations in the samples were not determined. Later on, Fiala et al. (1987) published several analyses of felsic granulites from the Běstvina Unit.

\subsection{Analytical methods}

Major-element whole-rock analyses were performed by wet chemical methods in the laboratory of the Czech Geological Survey, Prague. Minor and trace elements were analysed in the Acme Analytical Laboratories, Vancouver, Canada, using $\mathrm{LiBO}_{2} / \mathrm{Li}_{2} \mathrm{~B}_{4} \mathrm{O}_{7}$ fusion and ICP-MS/ES. Precious and base metals were determined by aqua regia digestion and ICP-MS.

Mineral analyses were carried out using the CAMECA SX 100 WDS electron microprobe at the Joint Laboratory of Electron Microscopy and Microanalysis, Institute of Geological Sciences, Masaryk University and Czech Geological Survey, Brno. The analytical conditions were adjusted to the type of mineral analysed, usually $15 \mathrm{kV}$ accelerating voltage, probe current 10-20 nA, acquisition time 10-30 s. The standards used were spessartine ( $\mathrm{Si}$, $\mathrm{Mn})$, almandine $(\mathrm{Fe})$, andradite $(\mathrm{Ca}), \mathrm{MgAl}_{2} \mathrm{O}_{4}(\mathrm{Mg})$, hornblende (Ti), sanidine $(\mathrm{Al}, \mathrm{K})$, albite $(\mathrm{Na})$, fluorapatite (P) and chromite $(\mathrm{Cr})$. Mineral abbreviations in this paper are those of Kretz (1983).

\section{Petrography}

\subsection{Fine-grained felsic gneisses}

Mineralogical and selected whole-rock geochemical indeces for the studied rocks are given in Tab. 1. The felsic rocks are very fine-grained, with garnet typically smaller than $2 \mathrm{~mm}$. Foliation planes are incompletely covered by 
Tab. 1 Mineralogy, oxide and element ratios in felsic gneisses and granulites

\begin{tabular}{|c|c|c|c|c|c|c|c|c|c|c|c|c|c|c|c|c|}
\hline $\begin{array}{l}\text { Sample } \\
\text { No. }\end{array}$ & Locality & WGS-84-N & WGS-84-E & Grt & Ms & $\mathbf{K y}$ & Du $A n_{M}$ & $A n_{N}$ & ASI & $\mathrm{FeO}^{\mathrm{t}}$ & $\mathrm{FeO}^{\mathrm{t} / \mathrm{MgO}}$ & $\mathrm{FeO}^{\mathrm{t} / \mathrm{MnO}}$ & $\mathrm{Zr} / \mathbf{H f}$ & $\begin{array}{l}\text { Total } \\
\text { REE }\end{array}$ & $\mathbf{L a}_{\mathrm{N}} / \mathbf{Y} \mathbf{b}_{\mathrm{N}}$ & $\mathbf{E u} / \mathbf{E u}$ \\
\hline 1 & Suchdol & $49^{\circ} 57^{\prime} 19.2^{\prime \prime}$ & $15^{\circ} 10^{\prime} 37.2^{\prime \prime}$ & + & + & + & + & 4 & 1.14 & 1.01 & 12.63 & 13.8 & 13.93 & 10.50 & 1.78 & 0.816 \\
\hline 2 & Bohouňovice quarry & $49^{\circ} 58^{\prime} 7.4^{\prime \prime}$ & $15^{\circ} 10^{\prime} 42.2^{\prime \prime}$ & + & + & + & + & 7 & 1.26 & 0.90 & 15.00 & 15.8 & 15.71 & 13.61 & 2.22 & 0.783 \\
\hline $501^{\dagger}$ & Bohouňovice quarry & $49^{\circ} 58^{\prime} 7.4^{\prime \prime}$ & $15^{\circ} 10^{\prime} 42.2^{\prime \prime}$ & + & + & + & + & & & & & & & & & \\
\hline 3 & Bohouňovice-Vysoká & 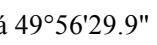 & $15^{\circ} 11^{\prime} 23.9^{\prime \prime}$ & $\operatorname{tr}$ & + & & + & 4 & 1.10 & 0.39 & 3.25 & 32.5 & 18.83 & 27.63 & 3.57 & 1.911 \\
\hline 4 & Kutná Hora-Bylanka & $49^{\circ} 56^{\prime} 30.8^{\prime \prime}$ & $15^{\circ} 14^{\prime} 52.7^{\prime \prime}$ & + & + & + & + & 2 & 1.18 & 0.78 & 11.14 & 10.3 & 19.00 & 7.99 & 2.80 & 0.430 \\
\hline 5 & Běstvina-Spačice & $49^{\circ} 49^{\prime} 7.3^{\prime \prime}$ & $15^{\circ} 35^{\prime} 26.7^{\prime \prime}$ & + & & + & 8 & 9 & 1.37 & 1.75 & 1.22 & 30.2 & 18.67 & 73.14 & 5.47 & 0.574 \\
\hline 6 & Běstvina-Spačice & $49^{\circ} 49^{\prime} 7.3^{\prime \prime}$ & $15^{\circ} 35^{\prime} 26.7^{\prime \prime}$ & + & & + & & & & & & & 22.67 & 24.96 & 4.77 & 0.634 \\
\hline 7 & Běstvina-Spačice & $49^{\circ} 49^{\prime} 2.7^{\prime \prime}$ & $15^{\circ} 35^{\prime} 15.1^{\prime \prime}$ & + & $\operatorname{tr}$ & + & 18 & 19 & 1.12 & 2.39 & 4.35 & 50.9 & & 103.55 & 4.50 & 0.470 \\
\hline 8 & Běstvina-Pařížov & $49^{\circ} 49^{\prime} 44.6^{\prime \prime}$ & $15^{\circ} 34^{\prime} 14.6^{\prime \prime}$ & + & & + & 15 & 17 & 1.23 & 2.39 & 4.35 & 45.1 & 27.10 & 105.02 & 4.08 & 0.346 \\
\hline 9 & Běstvina-Spačice & $49^{\circ} 49^{\prime} 17.8^{\prime \prime}$ & $15^{\circ} 35^{\prime} 50.7^{\prime \prime}$ & + & & + & 15 & 29 & 2.13 & 7.82 & 2.70 & 81.5 & 30.13 & 224.74 & 7.15 & 0.698 \\
\hline
\end{tabular}

Note:

$\mathrm{An}_{\mathrm{M}}$ - plagioclase composition measured, $\mathrm{An}_{\mathrm{N}}$ - normative plagioclase composition (CIPW), ASI - alumina saturation index, $\operatorname{tr}-\operatorname{traces}$ $\dagger-$ sample 501 was used for microprobe analyses of minerals and study of large relict Grt porphyroclasts

Rock types: 1-3 - Grt-Ky-Ms felsic gneiss; 4 - Grt-Bt-Ms-Ky leucosome; 5-6 - Grt-Ky felsic granulite (albitic); 7-8 - Grt-Ky felsic granulite (Běstvina Unit); 9 - Bt-Ky-Grt granulitic gneiss (metasedimentary)

muscovite. Quartz is commonly separated into monomineralic ribbons less than $1 \mathrm{~mm}$ thick, which alternate with feldspathic bands of albite and weakly perthitic finegrained ( 0.1 to $0.5 \mathrm{~mm}$ long) $\mathrm{K}$-feldspar. The latter bands contain kyanite (up to $\sim 3$ vol. \%) and/or muscovite (Fig. 3a). Lenticular porphyroclasts of $1 \mathrm{~mm}$ long K-feldspar and large primary (?) muscovite I are deformed to fishlike shapes (Fig. 3b). There are local aggregates, up to several $\mathrm{dm}^{2}$ in size, with coarse garnet $(6$ to $30 \mathrm{~mm}$ in diameter) intergrown with quartz. An additional sample 501 from the same outcrop as the sample 2 was used for characterization of the large garnet porphyroclasts and matrix minerals. In the matrix, garnet is present as anhedral crystals less than $1 \mathrm{~mm}$ in diameter. The modal contents of muscovite II and kyanite show variations (muscovite content from minor to $c .5$ vol. \%) across the foliation. Kyanite has not been observed as inclusions in garnet. Minor dumortierite forms violet fibrous aggregates in the felsic matrix; light blue dumortierite is rare. Apatite and subordinate graphite are accessories; apatite is pale yellow in thin sections and occurs locally as small porphyroclasts but exceptionally a single $1 \mathrm{~cm}$ long apatite crystal has been observed. Accessory tourmaline and rutile, reported by Fiala et al. (1982) and Fiala (1992), were not found.

Fig. 3 a - Kyanite and muscovite in Qtz-Ab-Kfs mylonitic matrix of felsic gneiss, sample 2, Bohouňovice; garnet is present in other parts of thin section; plain polarized light; $\mathbf{b}$ - Deformed porphyroclast of primary muscovite I rimmed by dumortierite $(\mathrm{Du})$ in mylonitic matrix of felsic gneiss, sample 2, Bohouňovice; crossed polarizers.
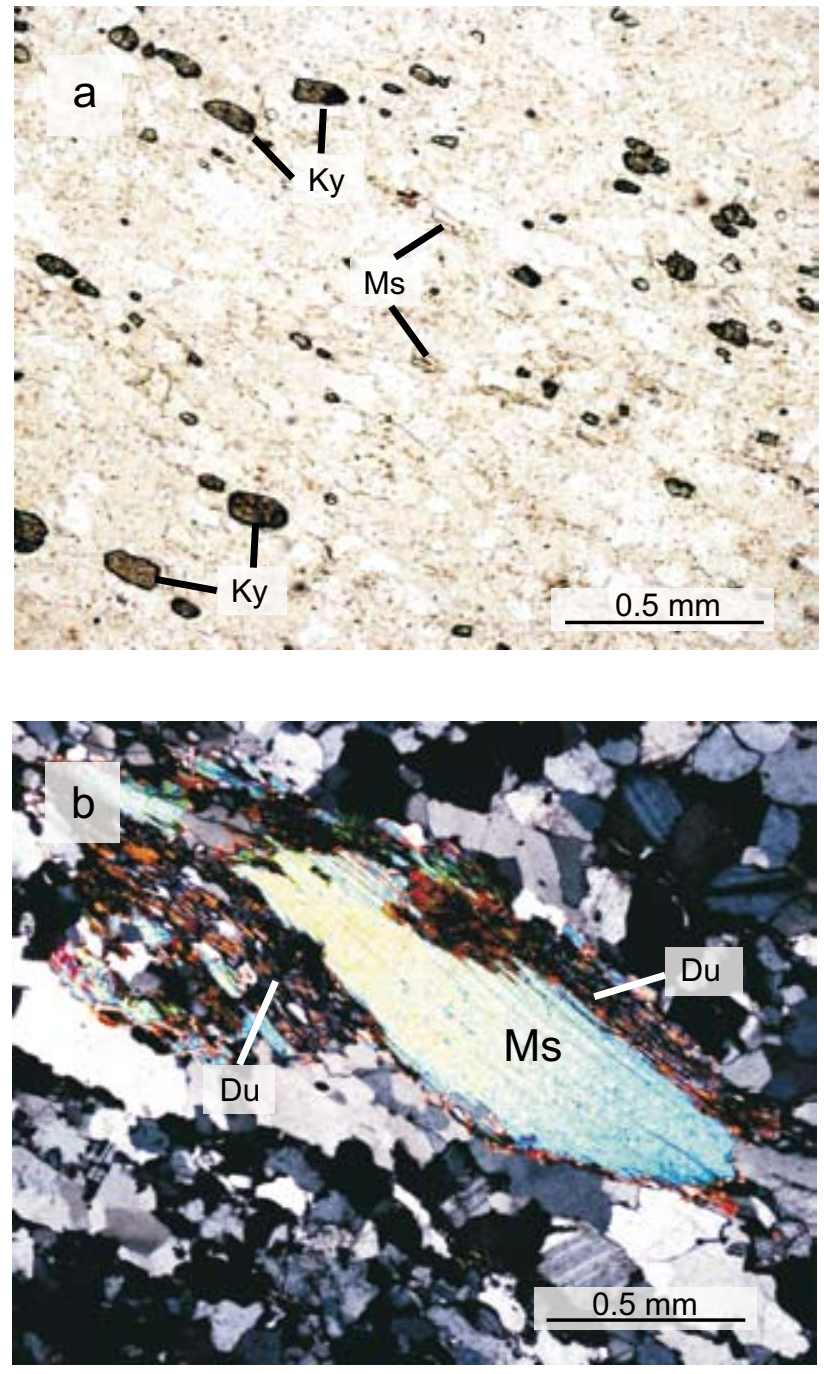
Sample 3 from the Vysoká Hill (Fig. 2) is somewhat different from samples 1 and 2 in that it contains only traces of garnet confined to local biotite-rich laminae. Garnet in this sample was probably extensively consumed by the reaction $\mathrm{Grt}+\mathrm{Kfs}+\mathrm{H}_{2} \mathrm{O} \rightarrow \mathrm{Bt}$. Biotite aggregates are seen on foliation planes as patches $5 \times 30 \mathrm{~mm}$ in size and less than $1 \mathrm{~mm}$ thick. The total biotite content in the rock is estimated to less than 3 vol. \%. In addition to biotite aggregates, foliation planes are partly covered by muscovite. Kyanite is absent in this sample, which may be a result of its replacement by muscovite. On a microscopic scale, there are two types of a late tourmaline: khaki-coloured anhedral grains nucleated at places with Ti available from biotite, followed by a low-Ti tourmaline of light bluish-green colour. The late, light bluish-green tourmaline is subhedral to euhedral, somewhat skeletal due to quartz inclusions, and rimmed by a narrow zone of quartz. Fibrous aggregates of violet dumortierite are present in the felsic matrix. The aggregates are oriented both parallel and across the mylonitic foliation, indicating, together with the skeletal and subhedral crystals of the bluish-green tourmaline, late post-mylonitic (post$\mathrm{D}_{3}$ ) crystallization of the borosilicates. Dumortierite and tourmaline are minor accessories, which occur in different domains of the samples and exhibit no reaction relationship.

\subsection{Foliated leucosome from polymetamorphic migmatite}

Sample 4 (Tab. 1) from the left tributary of the Bylanka brook in the outskirts of the city of Kutná Hora is another example of $\mathrm{Ab}-\mathrm{Kfs}$ garnet-kyanite-muscovite felsic rock in the KHC. The sample is dominated by pale pink feldspars and shows a mylonitic foliation. The foliation is defined by several $\mathrm{mm}$ long lenticular quartz aggregates grading to quartz ribbons, oriented flakes of early deformed muscovite I, 1-7 mm long, and $1 \times 3 \mathrm{~cm}$ aggregates of bluish kyanite, with individual crystals up to $3 \mathrm{~mm}$ in size. Garnet, relatively coarse kyanite and albite are pre-mylonitization phases, which can be used for pressure estimation of the early $\mathrm{HP} / \mathrm{HT} \mathrm{M}_{2}$ event. Biotite aggregates, marginally replacing garnet $(5 \mathrm{~mm}$ in diameter), or locally replacing older coarse muscovite I, can be observed. The foliation planes are partly covered by small, newly formed muscovite II. Rare xenoblastic khaki-coloured tourmaline up to $1 \mathrm{~mm}$ in diameter occurs intergrown with biotite in the proximity of garnet. Skeletal bluish-green tourmaline, similar to the tourmaline in the sample 3 , occurs locally along the boundary between the quartz ribbon and a feldspathic band. The rock contains numerous fibrous aggregates $(1 \mathrm{~mm}$ in diameter) of randomly oriented violet dumortierite. Dumortierite

Tab. 2 Major-element whole-rock chemical analyses for felsic gneisses and granulites (wt. \%)

\begin{tabular}{|c|c|c|c|c|c|c|c|c|}
\hline Sample No. & 1 & 2 & 3 & 4 & 5 & 7 & 8 & 9 \\
\hline $\begin{array}{c}\text { No. } \\
\text { Locality }\end{array}$ & $\begin{array}{c}\text { KK30G } \\
\text { Suchdol, } \\
\text { quarry }\end{array}$ & $\begin{array}{c}\text { KMV43 } \\
\text { Bohouňovice, } \\
\text { quarry }\end{array}$ & $\begin{array}{l}\text { KH47 } \\
\text { Vysoká }\end{array}$ & $\begin{array}{c}\text { KH126 } \\
\text { Bylanka }\end{array}$ & $\begin{array}{l}\text { MF153 } \\
\text { Spačice }\end{array}$ & $\begin{array}{l}\text { KK72S } \\
\text { Spačice }\end{array}$ & $\begin{array}{c}\text { KMV98 } \\
\text { Pařížov, dam }\end{array}$ & $\begin{array}{c}\text { MF7 } \\
\text { Spačice, north }\end{array}$ \\
\hline $\mathrm{SiO}_{2}$ & 74.64 & 74.03 & 73.84 & 76.92 & 76.40 & 77.67 & 73.26 & 59.18 \\
\hline $\mathrm{TiO}_{2}$ & 0.03 & 0.01 & 0.07 & 0.04 & 0.14 & 0.09 & 0.10 & 0.50 \\
\hline $\mathrm{Al}_{2} \mathrm{O}_{3}$ & 14.41 & 14.97 & 14.46 & 12.85 & 12.91 & 10.78 & 13.96 & 19.58 \\
\hline $\mathrm{Fe}_{2} \mathrm{O}_{3}$ & 0.22 & 0.16 & - & - & 0.35 & 0.23 & 0.26 & 1.11 \\
\hline $\mathrm{FeO}$ & 0.81 & 0.76 & - & - & 1.43 & 2.18 & 2.16 & 6.82 \\
\hline $\mathrm{Fe}_{2} \mathrm{O}_{3}{ }^{\mathrm{t}}$ & - & - & 0.43 & 0.87 & - & - & - & - \\
\hline $\mathrm{MnO}$ & 0.073 & 0.057 & 0.012 & 0.076 & 0.058 & 0.047 & 0.053 & 0.096 \\
\hline $\mathrm{MgO}$ & 0.08 & 0.06 & 0,12 & 0.07 & 1.43 & 0.55 & 0.55 & 2.90 \\
\hline $\mathrm{CaO}$ & 0.62 & 0.77 & 0.70 & 0.48 & 0.86 & 1.08 & 1.13 & 1.62 \\
\hline $\mathrm{Li}_{2} \mathrm{O}$ & - & - & 0.002 & 0.002 & 0.023 & - & 0.007 & 0.011 \\
\hline $\mathrm{Na}_{2} \mathrm{O}$ & 4.59 & 4.18 & 4.45 & 3.86 & 3.21 & 1.89 & 2.76 & 2.12 \\
\hline $\mathrm{K}_{2} \mathrm{O}$ & 3.72 & 3.38 & 4.19 & 3.40 & 2.38 & 4.19 & 4.42 & 2.57 \\
\hline $\mathrm{P}_{2} \mathrm{O}_{5}$ & 0.201 & 0.210 & 0.325 & 0.262 & 0.246 & 0.243 & 0.148 & 0.140 \\
\hline $\mathrm{F}$ & 0.023 & 0.025 & - & - & 0.051 & 0.034 & 0.054 & 0.068 \\
\hline $\mathrm{CO}_{2}$ & - & - & - & - & 0.01 & - & $<0.01$ & 0.01 \\
\hline $\mathrm{C}$ & - & - & - & - & $<0.005$ & - & 0.026 & 0.060 \\
\hline S & - & - & - & - & $<0.005$ & - & $<0.005$ & 0.209 \\
\hline $\mathrm{H}_{2} \mathrm{O}^{+}$ & 0.37 & LOI 0.61 & LOI 0.56 & LOI 0.41 & 0.40 & 0.25 & 0.37 & 0.61 \\
\hline $\mathrm{H}_{2} \mathrm{O}^{-}$ & $<0.05$ & 0.08 & 0.10 & 0.05 & 0.10 & 0.12 & 0.07 & 0.07 \\
\hline Total & 99.81 & 99.30 & 99.26 & 99.28 & 99.21 & 99.34 & 99.39 & 97.75 \\
\hline
\end{tabular}


cross-cutting the mylonitic foliation can be observed. The total content of borosilicates is less than $0.5 \mathrm{vol}$. \%. There was found a single grain of a complex rutile-niobian rutile intergrowth, $1.2 \mathrm{~mm}$ in diameter, surrounded by biotite. Rutile host with $0.8 \mathrm{wt}$. $\% \mathrm{Nb}_{2} \mathrm{O}_{5}$ carries unmixed lamellae of niobian-ferroan rutile, which have high- $\mathrm{Nb}$ rims with 14.53 wt. $\% \mathrm{Nb}_{2} \mathrm{O}_{5}$ and 5.27 wt. \% FeO. The whole-rock value of $3 \mathrm{ppm} \mathrm{Nb}$ indicates that niobian rutile must be a very rare accessory.

\subsection{Kyanite-garnet-albite-K-feldspar granulite, Běstvina Unit}

Samples 5 and 6 are fine-grained rocks from the same outcrop with parallel fabric defined by a weak compositional banding. Garnet is present mainly in felsic patches up to $1.5 \mathrm{~cm}$ long, slightly elongated parallel to the foliation. The rest of the rocks is greyish-white and contains small amounts of fine-grained biotite in a felsic matrix. Sample 5 contains approx. 8 vol. \% of garnet, $5 \%$ kyanite, $4 \%$ biotite, $30 \%$ albite, $12-15 \%$ K-feldspar and $40 \%$ quartz. Owing to prevalence of albite, the rock is nearly free of mesoperthite. Rutile and apatite are accessories. Sample 8 (KMV98) contains 5 vol. \% Grt, $2 \%$ Bt and $1 \% \mathrm{Ky}$. Data for sample 9 (Tab. 1), which is a Bt-Ky-Grt HP/HT "paragneiss" from the Běstvina Unit, are included for comparison. It contains 16 vol. \% garnet, $8 \%$ biotite and $10 \%$ kyanite in addition to plagioclase, antiperthite and quartz plus minor pyrrhotite, rutile, apatite and graphite.

\section{Whole-rock geochemistry and mineral chemistry}

\subsection{Whole-rock geochemistry}

Some key geochemical parameters are summarised in Tab. 1 ; complete whole-rock major- and trace-element analyses are presented in Tabs 2 and 3. The felsic gneisses from $\mathrm{KHC}$ and calc-alkali felsic granulites from the Běstvina Unit are corundum-normative rocks with alumina saturation index (ASI) 1.10 to 1.26 , but the albite granulite sample 5 has ASI $=1.37$ and the metasedimentary granulite rich in Grt and Ky, sample 9, has a high ASI value of 2.13. The CIPW norms show that the kyanite-garnet-muscovite felsic gneisses (samples 1 to 3), the foliated leucosome from the migmatite (sample 4) and the albite granulites from the Běstvina Unit (samples 5 and 6) are all identified as albite-K-feldspar-quartz rocks in part chemically corresponding to alkali-feldspar granite. This feature is confirmed by comparison of the calculated plagioclase composition with actual microprobe analyses in Tab. 1. Samples 1, 2 and 4 have high $\mathrm{FeOt} / \mathrm{MgO}$ ratios between
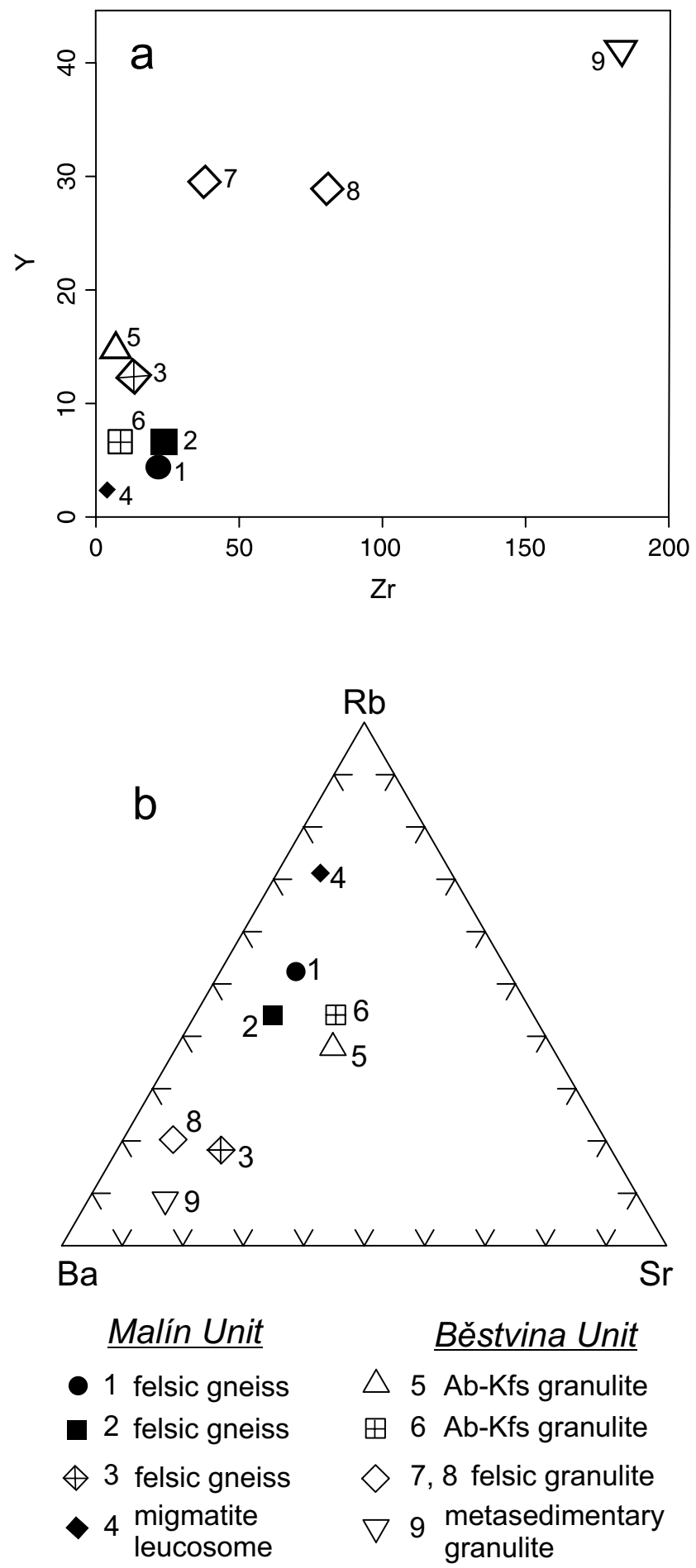

Fig. $4 \mathbf{a}$ - Variations in $\mathrm{Zr}$ and $\mathrm{Y}$ for the studied samples (ppm); $\mathbf{b}-\mathrm{Ba}$, $\mathrm{Rb}$ and $\mathrm{Sr}$ relations in the studied samples (ppm).

11.1 and 15.0 , but sample 3 is different, having $\mathrm{FeOt} / \mathrm{MgO}$ $=3.25$. Concentrations of certain elements and element/ element ratios, such as low $\mathrm{FeOt} / \mathrm{MnO}, \mathrm{Zr} / \mathrm{Hf}$ (Tab. 1), $\mathrm{Zr}$ and $\mathrm{Y}$ (Fig. 4a), high $\mathrm{Rb} / \mathrm{Sr}$ and $\mathrm{Rb} / \mathrm{Ba}$ ratios (Fig. 4b), together with low total REE contents (Fig. 5), can be used as valuable petrogenetic indicators. 
Tab. 3 Trace element whole-rock analyses of felsic gneisses and granulites (ppm)

\begin{tabular}{|c|c|c|c|c|c|c|c|c|c|}
\hline Sample No. & 1 & 2 & 3 & 4 & 5 & 6 & 7 & 8 & 9 \\
\hline $\begin{array}{c}\text { No. } \\
\text { Locality }\end{array}$ & $\begin{array}{c}\text { KK30G } \\
\text { Suchdol, quarry }\end{array}$ & $\begin{array}{c}\text { KMV43 } \\
\text { Bohouňovice }\end{array}$ & $\begin{array}{l}\text { KH47A } \\
\text { Vysoká }\end{array}$ & $\begin{array}{c}\text { KH126 } \\
\text { Bylanka }\end{array}$ & $\begin{array}{l}\text { MF153 } \\
\text { Spačice }\end{array}$ & $\begin{array}{l}\text { MF153A } \\
\text { Spačice }\end{array}$ & $\begin{array}{l}\text { KK72S } \\
\text { Spačice }\end{array}$ & $\begin{array}{c}\text { KMV98A } \\
\text { Pařížov, dam }\end{array}$ & $\begin{array}{c}\text { MF7 } \\
\text { Spačice, north }\end{array}$ \\
\hline $\mathrm{Be}$ & $<1$ & $<1$ & $<1$ & $<1$ & $<1$ & $<1$ & & $<1$ & $<1$ \\
\hline $\mathrm{Rb}$ & 90.5 & 67.2 & 106.3 & 115.1 & 124.1 & 110.7 & 130 & 132.4 & 85,0 \\
\hline $\mathrm{Sr}$ & 20.6 & 20.5 & 99.7 & 11.6 & 85.1 & 58.4 & 198 & 54.2 & 123.2 \\
\hline $\mathrm{Ba}$ & 60 & 67 & 376 & 35 & 119 & 82 & & 467 & 760 \\
\hline $\mathrm{Ni}$ & 0.7 & 1.3 & 3.0 & 1.7 & 63.0 & 9.6 & 8 & 2.9 & 99.9 \\
\hline $\mathrm{Co}$ & 0.6 & 0.4 & 0.4 & 0.5 & 3.1 & 2.5 & & 2.5 & 23.6 \\
\hline $\mathrm{V}$ & $<8$ & $<8$ & $<8$ & $<8$ & 22 & 21 & & 22 & 143 \\
\hline Mo & $<0.1$ & $<0.1$ & $<0.1$ & 0.1 & 11.2 & 0.2 & 1 & 0.2 & 2.9 \\
\hline $\mathrm{Sn}$ & 2 & 2 & 4 & 1 & 8 & 10 & $<2$ & $<1$ & $<1$ \\
\hline $\mathrm{Cu}$ & 1.8 & 1.5 & 2.2 & 2.9 & 4.5 & 4.4 & 1 & 2.3 & 70.3 \\
\hline $\mathrm{Zn}$ & 2 & 2 & 10 & 5 & 33 & 32 & 27 & 9 & 92 \\
\hline $\mathrm{Ga}$ & 15.9 & 16.8 & 14.2 & 14.1 & 17.0 & 18.4 & & 15.5 & 21.2 \\
\hline $\mathrm{Zr}$ & 20.9 & 22.0 & 11.3 & 3.8 & 5.6 & 6.8 & 38 & 81.3 & 183.8 \\
\hline Hf & 1.5 & 1.4 & 0.6 & 0.2 & 0.3 & 0.3 & & 3.0 & 6.1 \\
\hline $\mathrm{Nb}$ & 0.4 & 0.6 & 2.8 & 3.0 & 6.7 & 3.0 & 4 & 4.4 & 15.1 \\
\hline $\mathrm{Ta}$ & $<0.1$ & $<0.1$ & 0.5 & 0.1 & 0.2 & 0.2 & & $<0.1$ & 0.7 \\
\hline W & $<0.5$ & $<0.5$ & 0.7 & 0.9 & 2.2 & 1.0 & & $<0.5$ & 1.7 \\
\hline Th & 0.2 & 0.4 & 1.1 & 0.9 & 1.4 & 0.4 & & 1.3 & 14.5 \\
\hline $\mathrm{U}$ & 1.4 & 0.7 & 2.1 & 5.8 & 1.5 & 0.6 & $<2$ & 0.3 & 2.1 \\
\hline $\mathrm{La}$ & 1.9 & 2.5 & 4.4 & 1.7 & 11.6 & 4.1 & & 17.5 & 43.8 \\
\hline $\mathrm{Ce}$ & 3.3 & 4.8 & 9.1 & 2.7 & 32.4 & 9.4 & & 40.2 & 98.6 \\
\hline $\operatorname{Pr}$ & 0.35 & 0.52 & 1.09 & 0.32 & 3.13 & 1.17 & & 4.96 & 9.95 \\
\hline $\mathrm{Nd}$ & 1.5 & 1.7 & 4.0 & 1.3 & 13.0 & 4.9 & & 19.6 & 37.4 \\
\hline $\mathrm{Gd}$ & 0.46 & 0.55 & 1.68 & 0.30 & 2.65 & 1.13 & & 4.34 & 6.84 \\
\hline $\mathrm{Tb}$ & 0.12 & 0.15 & 0.39 & 0.07 & 0.50 & 0.21 & & 0.84 & 1.23 \\
\hline Dy & 0.84 & 1.00 & 2.26 & 0.46 & 2.83 & 1.16 & & 4.86 & 7.27 \\
\hline Ho & 0.14 & 0.22 & 0.40 & 0.07 & 0.45 & 0.21 & & 0.99 & 1.42 \\
\hline $\mathrm{Er}$ & 0.48 & 0.64 & 1.02 & 0.25 & 1.43 & 0.59 & & 2.94 & 4.16 \\
\hline $\mathrm{Tm}$ & 0.10 & 0.13 & 0.14 & 0.04 & 0.22 & 0.10 & & 0.48 & 0.64 \\
\hline $\mathrm{Yb}$ & 0.72 & 0.76 & 0.83 & 0.41 & 1.43 & 0.58 & & 2.89 & 4.13 \\
\hline $\mathrm{Lu}$ & 0.11 & 0.12 & 0.11 & 0.06 & 0.20 & 0.09 & & 0.41 & 0.61 \\
\hline $\mathrm{Y}$ & 4.7 & 6.2 & 12.5 & 2.4 & 14.8 & 6.4 & 29.6 & 29.0 & 41.2 \\
\hline
\end{tabular}

Somewhat surprisingly, the garnet-kyanite-muscovite migmatite leucosome (sample 4) is also an albitic rock with several features of highly evolved composition, such as low values of $\mathrm{Zr} / \mathrm{Hf}=19, \mathrm{FeOt} / \mathrm{MnO}=10$ and a low total REE contents. Trace-element data for samples 5 and 6 from the same outcrop in the Běstvina Unit show several geochemical features indicating a highly evolved, probably magmatic protolith. The rock has a low value $\mathrm{Zr} / \mathrm{Hf}=18.7$ and rather low $\mathrm{FeOt} / \mathrm{MnO}$ ratio of 30.2.

\subsection{Mineral chemistry}

Representative mineral compositions are given in Tabs 4-8.

\subsubsection{Garnet}

In samples 1 and 2 (fine-grained felsic gneiss), garnet is the only mafic mineral, typically less than $2 \mathrm{~mm}$ in diameter. It contains 80.0-82.9 mol. \% Alm, 7.9-12.9 \% Prp, 4.1-7.8 \% Sps, and 0.8-4.0 \% Grs (Tab. 4). Widely scattered, coarse relict garnet crystals in the same rock are represented by sample 501 (Tab. 4a) from Bohouňovice (Fig. 6a). The garnet compositional profile (Fig. 6b) exhibits a high Sps content in the central part up to 27.6 mol. \%, Grs $\sim 0$, and Prp of 5.6 to $7.4 \%$ (Fig. 6b). Figure 7 presents comparison of the radiating pattern of quartz-garnet intergrowth in sample 501 and in unmetamorphosed garnetiferous granite. The narrow rim zone of 

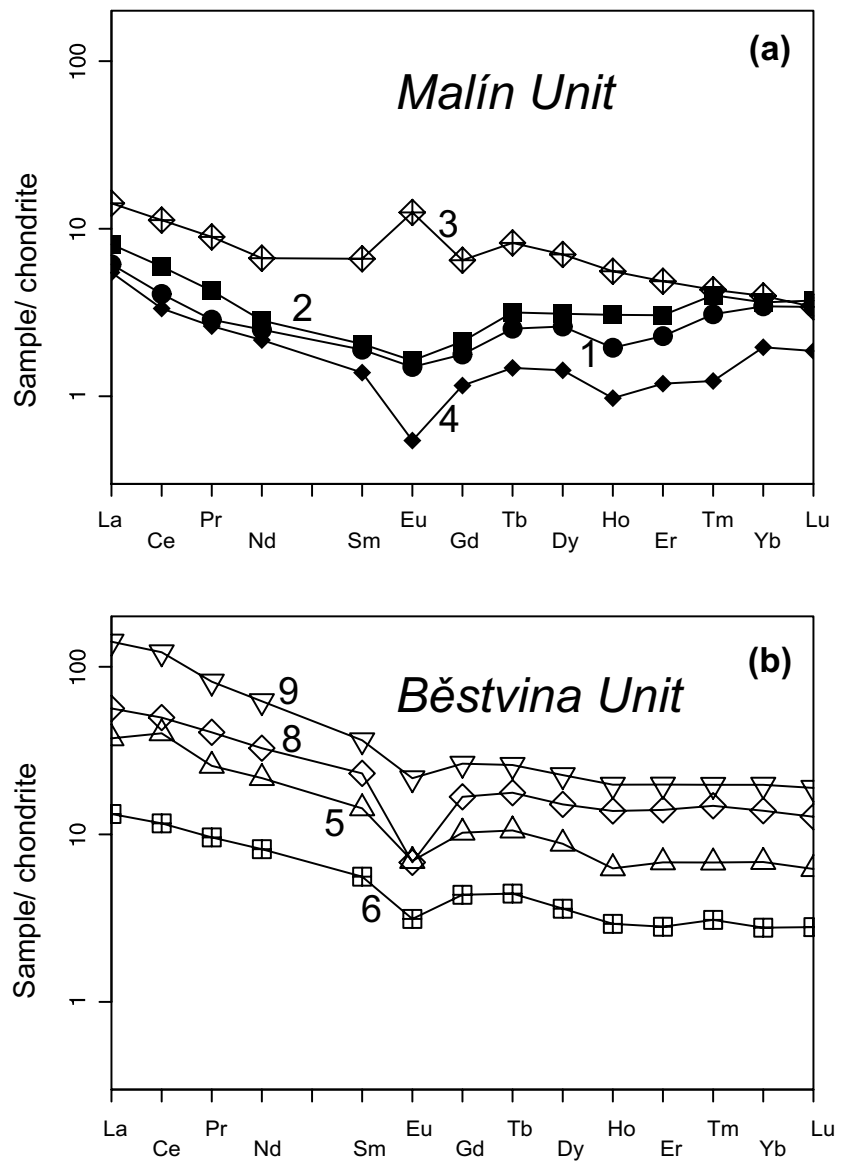

Fig. 5 Chondrite-normalized (Boynton 1984) REE distribution patterns for albite-K-feldspar felsic gneisses (1-3), leucosome of polymetamorphic migmatite (4) (all Malin Unit), felsic albite-K-feldspar (5-6) and calc-alkali granulites (8-9) from the Běstvina Unit.

large relict garnet and small garnet crystals $(<0.2 \mathrm{~mm}$ in diameter) in the mylonitic matrix of sample 501 have compositions with $2.0-7.5 \mathrm{~mol} \%$ Grs, 9.3-13.6 \% Prp, and $12.9-3.7 \% \mathrm{Sps}$, which is distinctly different from the composition of the central parts of the large relict garnet (Tab. 4, Fig. 6b). The rim composition of the garnet porphyroclasts probably evolved at a stage of matrix garnet growth or modification via diffusion $\left(\mathrm{M}_{3}\right)$, as indicated by the increased Grs and Prp components. Based on the available information, it is uncertain whether the small matrix garnets in samples 1, 2 and 501 represent a pre-metamorphic population with compositions strongly modified by diffusive metamorphic $\left(\mathrm{M}_{3}\right)$ re-equilibration, or a new garnet generation produced during the $\mathrm{M}_{3}$ metamorphism. The source of $\mathrm{Mg}$ leading to the increase in Prp in the small garnets in the matrix is uncertain. Possibly a small amount of primary biotite, consumed by Grt-producing reactions, was present.

Minute garnet grains in the biotite-rich laminae in sample 3 contain 83 mol. \% Alm, $10.1 \%$ Prp, $4.4 \%$ Sps and $1.7 \%$ Grs (Tab. 4).

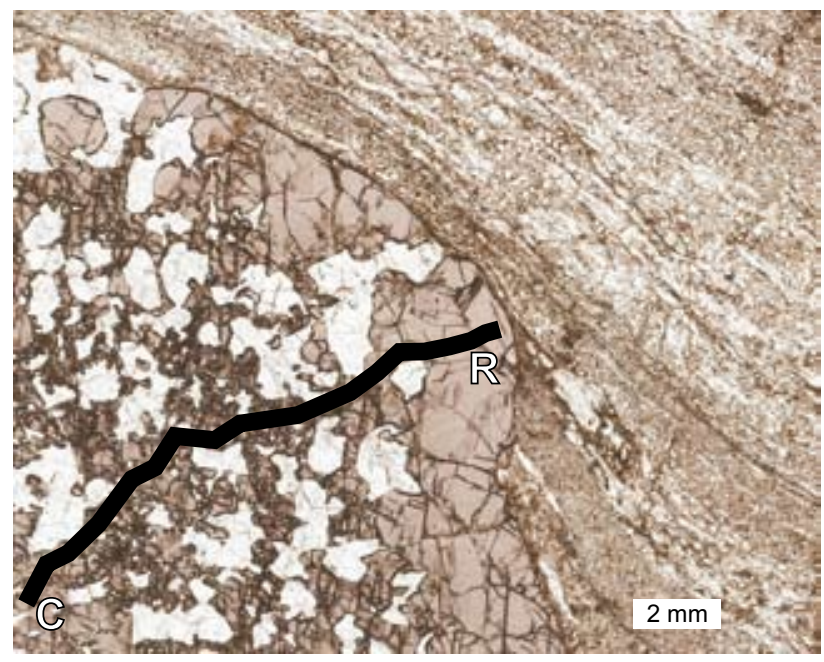

(a)
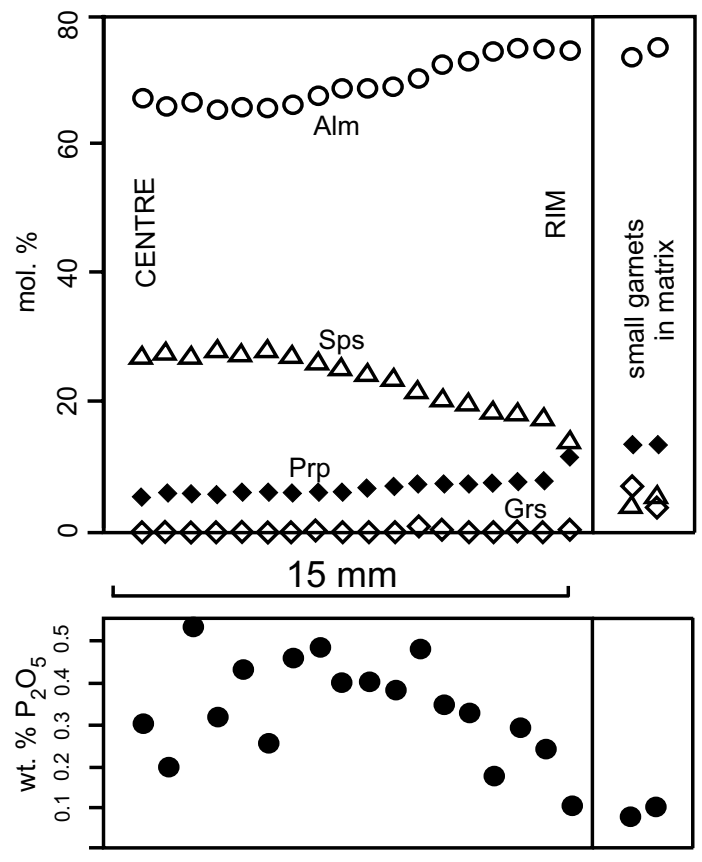

(b)

Fig. 6 a - Relict garnet porphyroclast in mylonitic matrix of kyanitegarnet-muscovite felsic gneiss from Bohouňovice, sample 501; location of compositional profile $\mathrm{C}-\mathrm{R}$ is indicated by a thick line; $\mathbf{b}$ - Compositional profile across relict garnet porphyroclast (sample 501); position is indicated in Fig. 6a.

Garnet in leucosome from the Bylanka migmatite (sample 4) forms crystals up to $5 \mathrm{~mm}$ in diameter and contains 72.2-76.5 mol. \% Alm, 16.2-21.5 \% Prp, $3.1-3.5 \%$ Sps, and $2.5-3.1 \%$ Grs. The elevated content of 0.05 to 0.10 wt. $\% \mathrm{Na}_{2} \mathrm{O}$ (Tab. 4) is interesting as a potential indication of ultra-high pressure conditions. Small garnet in the same sample shows lower Prp and Grs than the large crystal and contains $81.9 \mathrm{~mol}$. \% Alm, $12.5 \%$ Prp, $3.7 \%$ Sps, and $1.7 \%$ Grs. 
Tab. 4 Chemical composition of garnet (wt. \%, apfu and mol. \%)

\begin{tabular}{|c|c|c|c|c|c|c|c|c|c|c|}
\hline $\begin{array}{l}\text { Sample No. } \\
\text { Analysis No. }\end{array}$ & $\begin{array}{c}1 \\
89 c^{*}\end{array}$ & $\begin{array}{c}1 \\
96 r\end{array}$ & $\begin{array}{c}2 \\
77\end{array}$ & $\begin{array}{c}2 \\
78\end{array}$ & $\begin{array}{c}3 \\
41 c\end{array}$ & $\begin{array}{c}501 \\
15 \text { int }\end{array}$ & $\begin{array}{l}501 \\
19 \text { r }\end{array}$ & $\begin{array}{c}501 \\
22 \mathrm{sm}\end{array}$ & $\begin{array}{c}4 \\
5 r\end{array}$ & $\begin{array}{c}4 \\
2 c\end{array}$ \\
\hline $\mathrm{SiO}_{2}$ & 36.51 & 36.84 & 37.40 & 37.57 & 36.78 & 35.93 & 36.59 & 37.17 & 37.49 & 37.44 \\
\hline $\mathrm{TiO}_{2}$ & 0.00 & 0.00 & 0.01 & 0.00 & 0.00 & 0.00 & 0.00 & 0.00 & 0.03 & 0.07 \\
\hline $\mathrm{Al}_{2} \mathrm{O}_{3}$ & 20.84 & 20.96 & 21.06 & 21.29 & 20.75 & 20.78 & 20.60 & 20.91 & 20.94 & 20.83 \\
\hline $\mathrm{Cr}_{2} \mathrm{O}_{3}$ & 0.01 & 0.00 & 0.01 & 0.01 & 0.01 & 0.00 & 0.00 & 0.00 & 0.00 & 0.00 \\
\hline $\mathrm{FeO}^{\mathrm{t}}$ & 37.00 & 36.03 & 35.66 & 36.63 & 37.00 & 30.15 & 33.31 & 33.61 & 34.30 & 34.12 \\
\hline $\mathrm{MnO}$ & 3.35 & 3.13 & 1.89 & 1.81 & 1.89 & 11.71 & 5.56 & 1.64 & 1.52 & 1.18 \\
\hline $\mathrm{MgO}$ & 1.90 & 1.95 & 3.11 & 3.25 & 2.49 & 1.35 & 2.43 & 3.39 & 3.96 & 4.44 \\
\hline $\mathrm{CaO}$ & 0.55 & 1.69 & 0.93 & 0.73 & 0.85 & 0.45 & 1.37 & 3.02 & 1.28 & 1.16 \\
\hline $\mathrm{Na}_{2} \mathrm{O}$ & 0.08 & 0.02 & 0.02 & 0.01 & 0.02 & 0.06 & 0.00 & 0.01 & 0.05 & 0.10 \\
\hline $\mathrm{P}_{2} \mathrm{O}_{5}$ & 0.28 & 0.14 & - & - & 0.05 & 0.32 & 0.06 & 0.07 & 0.15 & 0.28 \\
\hline Total & 100.52 & 100.76 & 100.09 & 101.30 & 99.84 & 100.75 & 99.92 & 99.82 & 99.72 & 99.62 \\
\hline \multicolumn{11}{|c|}{ Number of ions ( 8 cats) } \\
\hline $\mathrm{Si}$ & 2.977 & 2.980 & 3.008 & 2.993 & 2.992 & 2.942 & 2.977 & 2.989 & 3.013 & 3.010 \\
\hline $\mathrm{Ti}$ & - & - & 0.001 & - & - & - & - & - & 0.002 & 0.004 \\
\hline $\mathrm{Al}^{\mathrm{IV}}$ & 0.023 & 0.020 & 0.000 & 0.007 & 0.008 & 0.058 & 0.023 & 0.011 & 0.000 & 0.000 \\
\hline $\mathrm{Al}^{\mathrm{VI}}$ & 1.981 & 1.980 & 1.998 & 1.993 & 1.983 & 1.952 & 1.955 & 1.972 & 1.984 & 1.975 \\
\hline $\mathrm{Cr}$ & 0.001 & - & 0.001 & 0.001 & 0.001 & - & - & - & - & - \\
\hline $\mathrm{Fe}^{3+}$ & 0.016 & 0.018 & 0.000 & 0.006 & 0.015 & 0.042 & 0.040 & 0.025 & 0.001 & 0.010 \\
\hline $\mathrm{Fe}^{2+}$ & 2.506 & 2.420 & 2.407 & 2.435 & 2.502 & 2.023 & 2.227 & 2.235 & 2.305 & 2.284 \\
\hline $\mathrm{Mn}$ & 0.231 & 0.214 & 0.129 & 0.122 & 0.130 & 0.812 & 0.383 & 0.112 & 0.103 & 0.080 \\
\hline $\mathrm{Mg}$ & 0.231 & 0.235 & 0.373 & 0.386 & 0.302 & 0.165 & 0.295 & 0.406 & 0.474 & 0.532 \\
\hline $\mathrm{Ca}$ & 0.048 & 0.146 & 0.080 & 0.062 & 0.074 & 0.042 & 0.119 & 0.260 & 0.110 & 0.100 \\
\hline \multicolumn{11}{|c|}{ End-member mol. \% } \\
\hline Alm & 82.8 & 80.0 & 80.5 & 80.9 & 83.1 & 65.4 & 73.2 & 74.0 & 76.8 & 76.0 \\
\hline Sps & 7.8 & 7.2 & 4.3 & 4.1 & 4.4 & 27.6 & 12.8 & 3.7 & 3.5 & 2.7 \\
\hline Prp & 7.8 & 7.9 & 12.5 & 12.9 & 10.1 & 5.6 & 9.9 & 13.6 & 15.9 & 17.9 \\
\hline Grs & 0.8 & 4.0 & 2.7 & 1.8 & 1.7 & 0.0 & 2.0 & 7.5 & 3.7 & 2.9 \\
\hline Adr & 0.8 & 0.9 & 0.0 & 0.3 & 0.7 & 1.4 & 2.0 & 1.2 & 0.1 & 0.5 \\
\hline Uvr & 0.0 & 0.0 & 0.0 & 0.0 & 0.0 & 0.0 & 0.0 & 0.0 & 0.0 & 0.0 \\
\hline
\end{tabular}

* $\mathrm{c}$ and $\mathrm{r}$ denote core and rim, respectively; int - interior part, sm - small grains in matrix

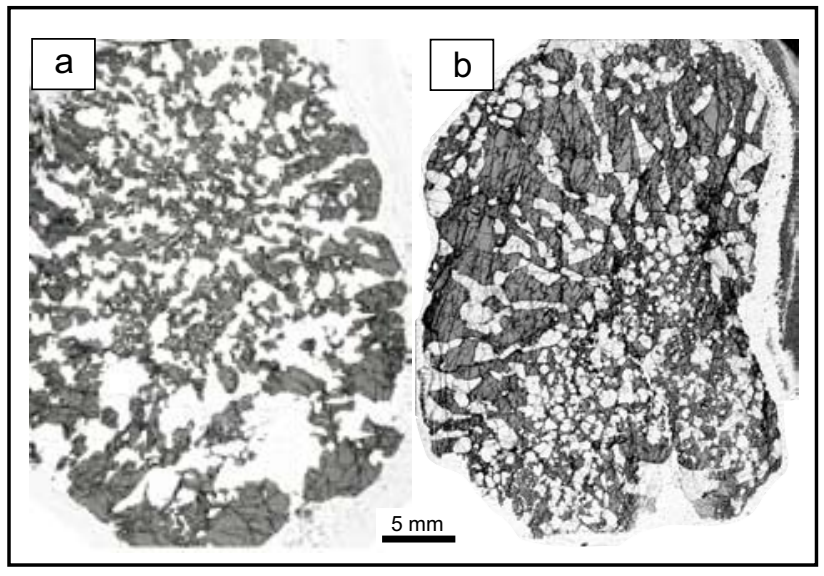

Fig. 7 a - Aggregate of intergrown Alm-Sps garnet and quartz from Ky-Grt-Ms felsic gneiss (sample 2, Bohouňovice); b - Aggregate of intergrown Alm-Sps garnet (Sps up to 13.3 mol. \%) and quartz from unmetamorphosed leucogranite dyke crosscutting Sil-Crd migmatite, Zajíčkov near Pelhřimov (Vrána 2005). Note the close similarity in the radiating pattern of quartz grains in garnet.
Garnet in the albitic granulite from the Běstvina Unit (sample 5) contains 57-62 mol. \% Alm, 31.5-32.5\% Prp, $3.6-6.6 \%$ Grs. The equant anhedral grains are free of any decompression reaction products. Garnet compositions in all samples are compared in Fig. 8.

\subsubsection{Feldspars}

Plagioclase from the felsic gneisses contains 5.3-8.0 mol. \% anorthite, 91.0-95.5\% albite, and 1.0-2.2\% orthoclase (Tab. 6). The K-feldspar contains $6.0-10.5$ mol. \% albite, $89.4-94.0 \%$ orthoclase, and up to $0.6 \%$ anorthite (Tab. 7).

\subsubsection{Tourmaline}

The migmatite leucosome (sample 4) contains two types of tourmaline that are very similar to those in sample 3 from Vysoká (Fig. 9), and an identical type of dumortierite. Ex- 
Tab. 4 Chemical composition of garnet (continued)

\begin{tabular}{|c|c|c|c|c|c|c|c|c|c|}
\hline $\begin{array}{c}\text { Sample No. } \\
\text { Analysis No. }\end{array}$ & $\begin{array}{c}4 \\
56\end{array}$ & $\begin{array}{c}5 \\
3 \mathrm{c}\end{array}$ & $\begin{array}{c}5 \\
4 r\end{array}$ & $\begin{array}{c}7 \\
48 c\end{array}$ & $\begin{array}{c}7 \\
38 \mathrm{r}\end{array}$ & $\begin{array}{c}8 \\
72 \mathrm{c}\end{array}$ & $\begin{array}{c}8 \\
71 r\end{array}$ & $\begin{array}{c}9 \\
19 \mathrm{c}\end{array}$ & $\begin{array}{c}9 \\
29 r\end{array}$ \\
\hline $\mathrm{SiO}_{2}$ & 37.34 & 38.94 & 38.89 & 37.80 & 37.68 & 38.47 & 38.42 & 39.23 & 38.85 \\
\hline $\mathrm{TiO}_{2}$ & 0.00 & 0.02 & 0.02 & 0.05 & 0.01 & 0.04 & 0.01 & 0.05 & 0.02 \\
\hline $\mathrm{Al}_{2} \mathrm{O}_{3}$ & 21.32 & 22.09 & 21.92 & 21.09 & 21.29 & 21.75 & 21.68 & 22.12 & 21.79 \\
\hline $\mathrm{Cr}_{2} \mathrm{O}_{3}$ & 0.00 & $<0.01$ & $<0.01$ & 0.00 & 0.02 & 0.01 & 0.03 & $<0.01$ & 0.02 \\
\hline $\mathrm{FeO}^{\mathrm{t}}$ & 37.05 & 27.35 & 29.16 & 29.56 & 31.37 & 26.61 & 31.11 & 25.63 & 27.24 \\
\hline $\mathrm{MnO}$ & 1.62 & 0.93 & 0.94 & 0.43 & 0.50 & 0.56 & 0.69 & 0.33 & 0.37 \\
\hline $\mathrm{MgO}$ & 3.12 & 8.54 & 8.23 & 5.92 & 6.96 & 6.78 & 6.07 & 9.28 & 8.83 \\
\hline $\mathrm{CaO}$ & 0.69 & 2.78 & 1.63 & 4.94 & 1.45 & 5.92 & 2.81 & 4.12 & 3.02 \\
\hline $\mathrm{Na}_{2} \mathrm{O}$ & 0.06 & 0.05 & 0.03 & 0.02 & 0.00 & 0.02 & 0.02 & $<0.01$ & $<0.01$ \\
\hline $\mathrm{P}_{2} \mathrm{O}_{5}$ & 0.57 & - & - & 0.10 & 0.03 & - & - & - & - \\
\hline Total & 101.77 & 100.70 & 100.82 & 99.91 & 99.31 & 100.16 & 100.84 & 100.76 & 100.14 \\
\hline \multicolumn{10}{|c|}{ Number of ions ( 8 cats) } \\
\hline $\mathrm{Si}$ & 2.984 & 2.988 & 2.993 & 2.974 & 2.979 & 2.982 & 2.995 & 2.984 & 2.987 \\
\hline $\mathrm{Ti}$ & & 0.001 & 0.002 & 0.003 & 0.000 & 0.002 & 0.001 & 0.003 & 0.001 \\
\hline $\mathrm{Al}^{\mathrm{IV}}$ & 0.016 & 0.012 & 0.007 & 0.026 & 0.021 & 0.018 & 0.005 & 0.016 & 0.013 \\
\hline $\mathrm{Al}^{\mathrm{VI}}$ & 1.993 & 1.986 & 1.981 & 1.934 & 1.965 & 1.970 & 1.988 & 1.969 & 1.967 \\
\hline $\mathrm{Cr}$ & - & - & - & - & 0.000 & 0.001 & 0.001 & - & 0.001 \\
\hline $\mathrm{Fe}^{3+}$ & 0.007 & 0.011 & 0.017 & 0.056 & 0.031 & 0.024 & 0.009 & 0.025 & 0.036 \\
\hline $\mathrm{Fe}^{2+}$ & 2.470 & 1.744 & 1.860 & 1.889 & 2.043 & 1.701 & 2.019 & 1.605 & 1.715 \\
\hline $\mathrm{Mn}$ & 0.110 & 0.060 & 0.062 & 0.029 & 0.043 & 0.037 & 0.046 & 0.021 & 0.024 \\
\hline $\mathrm{Mg}$ & 0.372 & 0.977 & 0.945 & 0.694 & 0.820 & 0.783 & 0.705 & 1.052 & 1.012 \\
\hline $\mathrm{Ca}$ & 0.059 & 0.229 & 0.135 & 0.416 & 0.123 & 0.494 & 0.235 & 0.336 & 0.249 \\
\hline \multicolumn{10}{|c|}{ End-member mol. \% } \\
\hline Alm & 81.9 & 57.6 & 61.9 & 61.7 & 67.2 & 55.9 & 67.1 & 52.8 & 57.0 \\
\hline Sps & 3.7 & 2.0 & 2.1 & 1.0 & 1.1 & 1.2 & 1.5 & 0.7 & 0.8 \\
\hline Prp & 12.5 & 32.7 & 31.5 & 23.3 & 27.5 & 26.3 & 23.6 & 35.2 & 33.8 \\
\hline Grs & 1.6 & 7.1 & 3.9 & 11.2 & 2.6 & 15.4 & 7.3 & 10.0 & 7.0 \\
\hline Adr & 0.3 & 0.6 & 0.6 & 2.8 & 1.5 & 1.2 & 0.5 & 1.3 & 1.3 \\
\hline Uvr & 0.0 & 0.0 & 0.0 & 0.0 & 0.0 & 0.0 & 0.0 & 0.0 & 0.1 \\
\hline
\end{tabular}
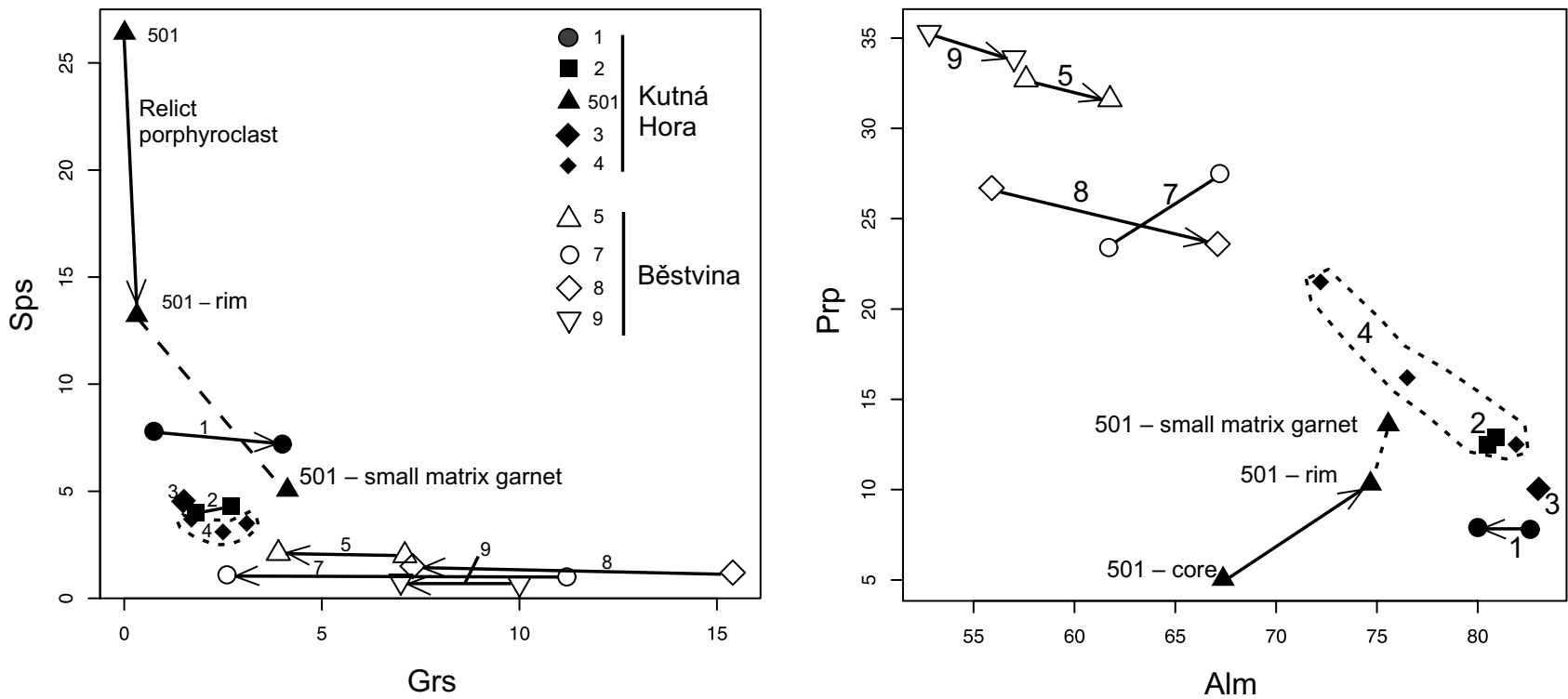

Fig. 8 Comparison of the garnet compositions for samples of kyanite-garnet-muscovite felsic gneisses from the vicinity of Kutná Hora (samples $1-4$, and 501) with garnets from granulites of the Běstvina Unit (samples 5, 7-9). Sample numbers and rock types are given in Tab. 1. 
Tab. 5 Chemical composition of biotite (wt. \% and apfu)

\begin{tabular}{|c|c|c|c|c|c|c|c|}
\hline Sample No. & 3 & 501 & 4 & 5 & 7 & 8 & 9 \\
\hline Anal. No. & $39 b$ & 23 & 50 & 16 & 37 & 75 & 22 \\
\hline $\mathrm{SiO}_{2}$ & 34.58 & 34.45 & 35.26 & 37.56 & 37.16 & 36.74 & 37.96 \\
\hline $\mathrm{TiO}_{2}$ & 3.45 & 0.24 & 2.60 & 4.42 & 4.14 & 3.94 & 4.42 \\
\hline $\mathrm{Al}_{2} \mathrm{O}_{3}$ & 19.55 & 20.95 & 20.11 & 16.89 & 16.93 & 18.30 & 17.78 \\
\hline $\mathrm{Cr}_{2} \mathrm{O}_{3}$ & 0.03 & 0.02 & 0.02 & 0.06 & 0.10 & 0.05 & 0.07 \\
\hline $\mathrm{FeO}$ & 22.74 & 20.48 & 20.54 & 13.77 & 12.09 & 14.82 & 10.81 \\
\hline $\mathrm{MgO}$ & 5.71 & 7.95 & 7.21 & 12.96 & 14.59 & 12.12 & 15.39 \\
\hline $\mathrm{CaO}$ & 0.07 & 0.07 & bd & bd & 0.04 & bd & bd \\
\hline $\mathrm{BaO}$ & $\mathrm{bd}$ & 0.03 & $\mathrm{bd}$ & - & - & - & - \\
\hline $\mathrm{Na}_{2} \mathrm{O}$ & 0.09 & 0.08 & 0.08 & 0.06 & 0.08 & 0.11 & 0.14 \\
\hline $\mathrm{K}_{2} \mathrm{O}$ & 8.77 & 9.09 & 9.08 & 9.73 & 9.16 & 9.43 & 9.43 \\
\hline $\mathrm{P}_{2} \mathrm{O}_{5}$ & 0.02 & 0.04 & 0.04 & - & bd & - & - \\
\hline $\mathrm{F}$ & 0.07 & bd & $\mathrm{bd}$ & - & - & - & - \\
\hline $\mathrm{Cl}$ & 0.01 & 0.01 & 0.03 & - & - & - & - \\
\hline Total & 95.38 & 93.51 & 95.20 & 95.53 & 94.29 & 95.51 & 96.04 \\
\hline \multicolumn{8}{|c|}{ Number of ions $24(\mathrm{O}, \mathrm{OH}, \mathrm{F})$} \\
\hline $\mathrm{Si}$ & 5.340 & 5.363 & 5.143 & 5.551 & 5.508 & 5.447 & 5.485 \\
\hline $\mathrm{Ti}$ & 0.401 & 0.028 & 0.312 & 0.491 & 0.462 & 0.439 & 0.480 \\
\hline $\mathrm{Al}^{\mathrm{IV}}$ & 2.660 & 2.637 & 2.857 & 2.449 & 2.492 & 2.553 & 2.515 \\
\hline $\mathrm{Al}^{\mathrm{VI}}$ & 0.899 & 1.207 & 0.922 & 0.493 & 0.466 & 0.644 & 0.513 \\
\hline $\mathrm{Cr}$ & 0.004 & 0.003 & 0.003 & 0.007 & 0.012 & 0.006 & 0.008 \\
\hline $\mathrm{Fe}^{2+}$ & 2.937 & 2.666 & 2.739 & 1.702 & 1.499 & 1.837 & 1.306 \\
\hline $\mathrm{Mn}$ & 0.012 & 0.013 & 0.024 & 0.010 & - & - & 0.005 \\
\hline $\mathrm{Mg}$ & 1.314 & 1.845 & 1.714 & 2.855 & 3.224 & 2.678 & 3.315 \\
\hline $\mathrm{Ca}$ & 0.012 & 0.012 & - & - & 0.006 & - & - \\
\hline $\mathrm{Na}$ & 0.027 & 0.024 & 0.025 & 0.017 & 0.023 & 0.032 & 0.039 \\
\hline $\mathrm{K}$ & 1.728 & 1.805 & 1.846 & 1.834 & 1.723 & 1.783 & 1.738 \\
\hline $\mathrm{Zn}$ & 0.023 & - & - & - & - & - & - \\
\hline $\mathrm{F}$ & 0.034 & - & - & - & - & - & - \\
\hline $\mathrm{Cl}$ & 0.003 & - & - & - & - & - & - \\
\hline
\end{tabular}

cept for differences in the Ti content, the composition of the two types of tourmaline in sample 3 is very similar (Tab. 8, Fig. 10) and corresponds to dravite-schorl (Selway and Novák 1997), with Mg prevailing over Fe. Our samples of felsic gneisses contain no evidence of primary tourmaline.

\subsubsection{Dumortierite}

Compared to the composition of igneous dumortierite in common pegmatites (Fiala 1954; Losert 1956a; Cempírek and Novák 2006), the metamorphic dumortierite of the studied samples (Tab. 8, Fig. 9) shows somewhat higher $\mathrm{Ti}, \mathrm{Fe}$ and $\mathrm{Mg}$ contents $\left(0.20-0.83\right.$ wt. $\% \mathrm{TiO}_{2}$, $1.02-1.20 \% \mathrm{MgO}$ and $0.23-0.25 \%$ FeOt $)$.

\section{Geothermobarometry}

Pressure and temperature calculations were performed using the garnet-alumina silicate-plagioclase (GASP) barometer of Koziol and Newton (1988). Garnet-biotite thermometry was carried out using the methods of Ferry and Spear (1978), Indares and Martignole (1985) and Williams and Grambling (1990). The results of P-T calculations are presented in Fig. 11. The set of Excel spreadsheet programs (Reche and Martinez 1996) was used for P-T calculations. The equation by Williams and Grambling (1990) was proposed for medium-grade GrtBt pairs, in which Grt has $X<0.1 \mathrm{Ca}$, biotite contains less than 2.4 wt. $\% \mathrm{TiO}_{2}$ and $10 \%$ of total iron in biotite is recalculated to $\mathrm{Fe}_{2} \mathrm{O}_{3}$. In our sample set, especially in samples of the HP/HT granulites from the Běstvina Unit,

Fig. 9 Microstructures of tourmaline $(a-d)$ and dumortierite $(e-f)$ in albite-K-feldspar felsic gneiss, sample 3, Vysoká; a - Early khaki tourmaline; $\mathbf{b}$ - Khaki tourmaline core overgrown by light blue-green subhedral tourmaline; c-d - Subhedral light blue-green tourmaline with quartz inclusions and narrow rims of quartz; $\mathbf{e}-$ Violet dumortierite (Du) in quartz-feldspar matrix, (a to e - transmitted light photomicrographs with single polarizer), f-Quartz-dumortierite intergrowth, BSE image. See explanation in text. 
Tab. 6 Chemical composition of plagioclase (wt. \% and apfu)

\begin{tabular}{|c|c|c|c|c|c|c|c|c|c|c|c|}
\hline Sample No. & 1 & 2 & 3 & 501 & 4 & 5 & 5 & 7 & 8 & 9 & 9 \\
\hline Analysis No. & 65 & 81 & $8 \mathbf{b}$ & 26 & 57 & 5 & 6 & 164 & 73 & 25 & 26 \\
\hline $\mathrm{SiO}_{2}$ & 67.65 & 66.68 & 66.70 & 65.71 & 67.68 & 66.69 & 66.78 & 63.98 & 65.06 & 65.11 & 65.66 \\
\hline $\mathrm{Al}_{2} \mathrm{O}_{3}$ & 20.17 & 20.98 & 20.53 & 21.10 & 20.77 & 21.01 & 21.06 & 22.29 & 22.14 & 22.08 & 21.84 \\
\hline $\mathrm{FeOt}$ & bd & 0.24 & 0.01 & 0.02 & $\mathrm{bd}$ & 0.01 & bd & 0.04 & bd & bd & bd \\
\hline $\mathrm{CaO}$ & 1.09 & 1.69 & 1.05 & 1.89 & 0.84 & 1.75 & 1.86 & 3.66 & 3.20 & 3.22 & 2.82 \\
\hline $\mathrm{Na}_{2} \mathrm{O}$ & 10.64 & 10.62 & 11.08 & 10.62 & 11.52 & 10.62 & 10.44 & 8.96 & 9.73 & 9.91 & 9.93 \\
\hline $\mathrm{K}_{2} \mathrm{O}$ & 0.39 & 0.26 & 0.15 & 0.17 & 0.17 & 0.24 & 0.30 & 0.50 & 0.37 & 0.34 & 0.26 \\
\hline $\mathrm{BaO}$ & - & 0.11 & bd & bd & bd & - & - & - & - & - & - \\
\hline $\mathrm{SrO}$ & - & - & 0.03 & - & 0.05 & - & - & - & - & - & - \\
\hline $\mathrm{PbO}$ & - & - & 0.05 & - & bd & - & - & - & - & - & - \\
\hline $\mathrm{P}_{2} \mathrm{O}_{5}$ & 0.10 & 0.24 & 0.15 & 0.05 & 0.28 & 0.06 & 0.10 & 0.02 & bd & 0.07 & 0.03 \\
\hline Total & 100.04 & 100.82 & 99.75 & 99.56 & 101.31 & 100.38 & 100.54 & 99.45 & 100.50 & 100.73 & 100.54 \\
\hline \multicolumn{12}{|c|}{ Number of ions ( 5 cats) } \\
\hline $\mathrm{Si}$ & 2.970 & 2.916 & 2.931 & 2.899 & 2.927 & 2.919 & 2.923 & 2.850 & 2.856 & 2.850 & 2.880 \\
\hline $\mathrm{Al}$ & 1.050 & 1.081 & 1.063 & 1.093 & 1.059 & 1.084 & 1.087 & 1.171 & 1.145 & 1.139 & 1.129 \\
\hline $\mathrm{Fe}^{2+}$ & 0.000 & 0.009 & 0.000 & 0.001 & - & 0.000 & - & 0.001 & - & - & - \\
\hline $\mathrm{Ca}$ & 0.050 & 0.079 & 0.049 & 0.090 & 0.039 & 0.082 & 0.087 & 0.175 & 0.151 & 0.151 & 0.133 \\
\hline $\mathrm{Na}$ & 0.910 & 0.900 & 0.944 & 0.908 & 0.966 & 0.901 & 0.886 & 0.774 & 0.828 & 0.841 & 0.845 \\
\hline $\mathrm{K}$ & 0.020 & 0.015 & 0.008 & 0.010 & 0.009 & 0.013 & 0.017 & 0.028 & 0.021 & 0.019 & 0.015 \\
\hline $\mathrm{P}$ & - & - & 0.006 & - & 0.010 & - & - & - & - & - & - \\
\hline $\mathrm{Ab}$ & 92.5 & 91.0 & 94.0 & 90.2 & 95.0 & 90.4 & 89.5 & 79.2 & 82.9 & 83.2 & 85.2 \\
\hline An & 5.3 & 8.0 & 5.0 & 8.9 & 4.0 & 8.2 & 8.8 & 17.9 & 15.1 & 14.9 & 13.4 \\
\hline Or & 2.2 & 1.0 & 1.0 & 0.9 & 1.0 & 1.3 & 1.7 & 2.9 & 2.1 & 1.9 & 1.5 \\
\hline
\end{tabular}
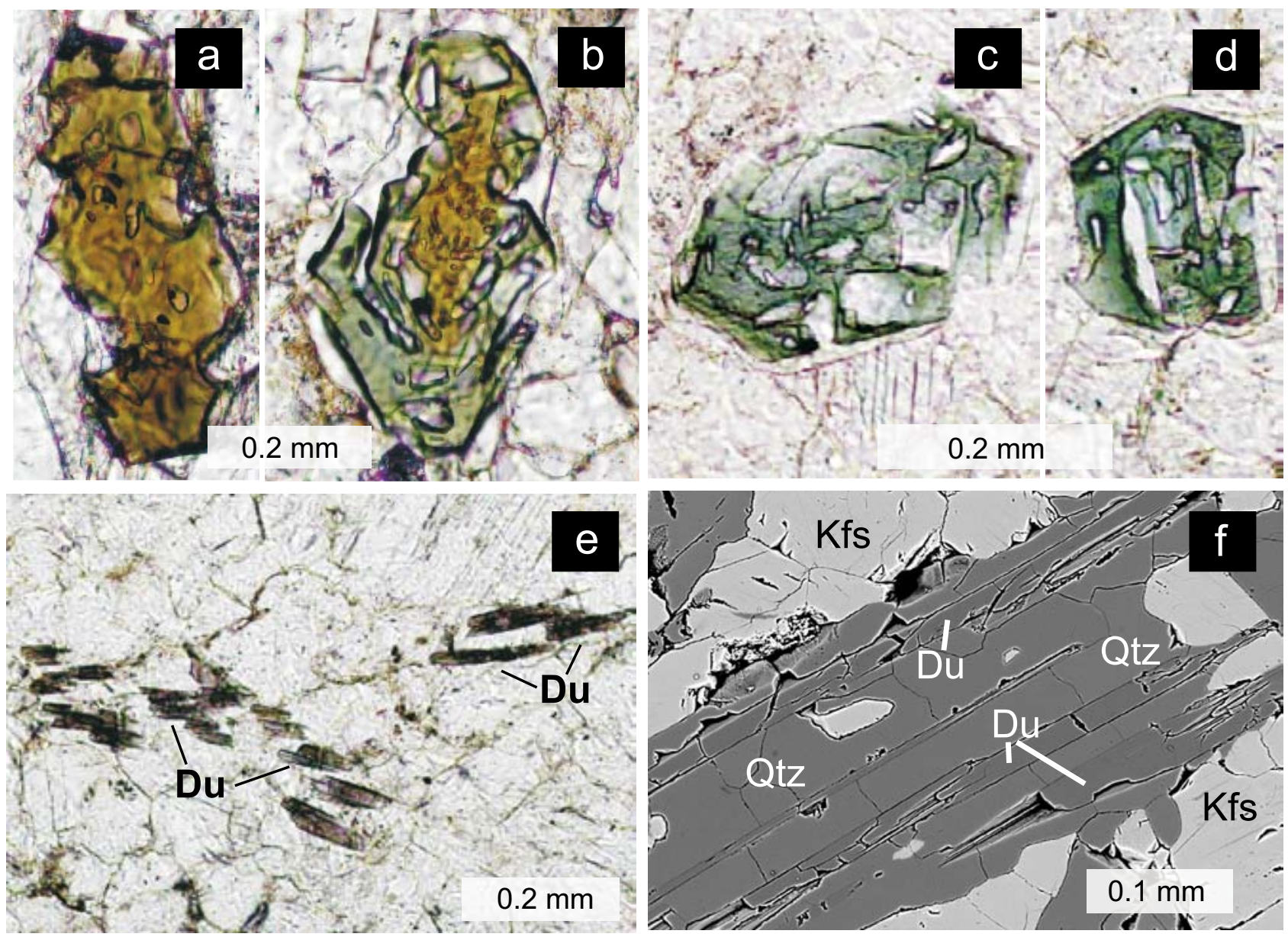
Tab. 7 Chemical composition of K-feldspar and muscovite (wt. \% and apfu)

\begin{tabular}{|c|c|c|c|c|}
\hline Mineral & Kfs & Kfs & Kfs & Kfs \\
\hline Sample & 2 & 3 & 501 & 7 \\
\hline Analysis No. & 84 & $13 b$ & 27 & 165 \\
\hline $\mathrm{SiO}_{2}$ & 64.67 & 64.37 & 64.94 & 64.32 \\
\hline $\mathrm{TiO}_{2}$ & - & - & - & - \\
\hline $\mathrm{Al}_{2} \mathrm{O}_{3}$ & 18.59 & 18.44 & 18.45 & 18.70 \\
\hline $\mathrm{Cr}_{2} \mathrm{O}_{3}$ & - & - & - & - \\
\hline $\mathrm{FeOt}$ & 0.24 & 0.00 & 0.00 & 0.01 \\
\hline $\mathrm{MnO}$ & - & - & - & - \\
\hline $\mathrm{MgO}$ & - & - & - & - \\
\hline $\mathrm{CaO}$ & 0.00 & 0.00 & 0.05 & 0.11 \\
\hline $\mathrm{SrO}$ & - & 0.09 & - & - \\
\hline $\mathrm{Na}_{2} \mathrm{O}$ & 0.63 & 1.01 & 1.40 & 1.53 \\
\hline $\mathrm{K}_{2} \mathrm{O}$ & 15.70 & 14.88 & 14.66 & 14.27 \\
\hline $\mathrm{BaO}$ & 0.03 & 0.10 & 0.01 & \\
\hline $\mathrm{P}_{2} \mathrm{O}_{5}$ & 0.16 & 0.32 & 0.39 & 0.02 \\
\hline Total & 99.99 & 99.20 & 99.90 & 98.96 \\
\hline \multicolumn{5}{|c|}{ Number of ions based on 5 cations } \\
\hline $\mathrm{Si}$ & 2.993 & 2.981 & 3.002 & 2.978 \\
\hline $\mathrm{Al}^{\mathrm{IV}}$ & 1.014 & 1.007 & 1.005 & 1.024 \\
\hline $\mathrm{Al}^{\mathrm{VI}}$ & - & - & - & - \\
\hline $\mathrm{Ti}$ & - & - & - & - \\
\hline $\mathrm{Cr}$ & - & - & - & - \\
\hline $\mathrm{Fe}^{2+}$ & 0.009 & 0.000 & 0.000 & 0.000 \\
\hline Mn & - & - & - & - \\
\hline $\mathrm{Mg}$ & - & - & - & - \\
\hline $\mathrm{Ca}$ & 0.000 & 0.000 & 0.002 & 0.005 \\
\hline $\mathrm{Na}$ & 0.057 & 0.091 & 0.125 & 0.138 \\
\hline $\mathrm{K}$ & 0.927 & 0.879 & 0.865 & 0.845 \\
\hline $\mathrm{P}$ & - & 0.012 & - & - \\
\hline Or & 94.0 & 94.0 & 87.2 & 85.1 \\
\hline $\mathrm{Ab}$ & 6.0 & 5.0 & 12.6 & 13.9 \\
\hline An & 0.0 & 1.0 & 0.2 & 0.5 \\
\hline
\end{tabular}

the interpretation of the geothermometric calculations is difficult, because of the relatively extreme conditions of metamorphism. Garnet in samples 5 to 9 has $X<0.1 \mathrm{Ca}$ (with one exception) and contains very low amount of MnO. Alcock (1996) presented data indicating that the effect of the grossular content on the Fe-Mg miscibility in Grt and Bt is small and is offset by other variables. Rather high Ti content in biotite, near 4 wt. \%, may represent a deviation from biotite compositions used by Williams and Grambling (1990). Ilmenite in granulites from the Běstvina Unit is free of unmixed hematite and the $\mathrm{FeO}$ and $\mathrm{TiO}_{2}$ ratios indicate minimal $\mathrm{Fe}^{3+}$ in solid solution. Some of the felsic granulite samples contain accessory graphite. These features show that the studied sample set equilibrated at lower oxygen fugacity compared to the samples studied by Williams and Grambling (1990). Consequently, correction of biotite composition for a presumed $\mathrm{Fe}^{3+}$ content was omitted. The calculated Grt-Bt temperature estimates using the Ferry and Spear (1978) thermometer are approximately by $50{ }^{\circ} \mathrm{C}$ lower

\begin{tabular}{|c|c|c|c|c|c|}
\hline Mineral & Ms II & Ms II & Ms II & Ms II & Ms I \\
\hline Sample & 1 & 2 & 3 & 501 & 4 \\
\hline Analysis No. & 74 & 82 & $7 b$ & 24 & 7 \\
\hline $\mathrm{SiO}_{2}$ & 46.31 & 46.69 & 47.52 & 47.45 & 48.09 \\
\hline $\mathrm{TiO}_{2}$ & 1.01 & 0.37 & 1.22 & 0.35 & 0.54 \\
\hline $\mathrm{Al}_{2} \mathrm{O}_{3}$ & 34.34 & 34.25 & 32.58 & 34.71 & 33.15 \\
\hline $\mathrm{Cr}_{2} \mathrm{O}_{3}$ & 0.01 & 0,00 & 0.00 & 0.01 & 0.01 \\
\hline $\mathrm{FeOt}$ & 1.34 & 1.49 & 1.26 & 1.14 & 1.42 \\
\hline $\mathrm{MnO}$ & 0.00 & 0.01 & 0.01 & 0.01 & 0.01 \\
\hline $\mathrm{MgO}$ & 0.53 & 1.01 & 1.28 & 0.93 & 1.38 \\
\hline $\mathrm{CaO}$ & 0.00 & 0.02 & 0.00 & 0.00 & 0.07 \\
\hline $\mathrm{Na}_{2} \mathrm{O}$ & 0.51 & 0.55 & 0.37 & 0.41 & 0.70 \\
\hline $\mathrm{K}_{2} \mathrm{O}$ & 10.37 & 10.46 & 10.55 & 11.23 & 10.04 \\
\hline $\mathrm{BaO}$ & - & - & - & 0.10 & - \\
\hline $\mathrm{F}$ & - & - & 0.21 & 0.04 & 0.09 \\
\hline $\mathrm{Cl}$ & - & - & 0.01 & 0.00 & 0.00 \\
\hline Total & 94.42 & 94.85 & 95.10 & 96.38 & 95.54 \\
\hline \multicolumn{6}{|c|}{ Number of ions based on $24(\mathrm{O}, \mathrm{OH}, \mathrm{F})$} \\
\hline $\mathrm{Si}$ & 6.217 & 6.245 & 6.352 & 6.261 & 6.371 \\
\hline $\mathrm{Al}^{\mathrm{IV}}$ & 1.783 & 1.755 & 1.648 & 1.739 & 1.629 \\
\hline $\mathrm{Al}^{\mathrm{VI}}$ & 3.650 & 3.645 & 3.486 & 3.660 & 3.548 \\
\hline $\mathrm{Ti}$ & 0.102 & 0.037 & 0.123 & 0.035 & 0.054 \\
\hline $\mathrm{Cr}$ & 0.001 & 0.000 & - & 0.001 & 0.001 \\
\hline $\mathrm{Fe}^{2+}$ & 0.150 & 0.167 & 0.141 & 0.126 & 0.157 \\
\hline $\mathrm{Mn}$ & 0.000 & 0.001 & 0.001 & 0.001 & 0.001 \\
\hline $\mathrm{Mg}$ & 0.106 & 0.201 & 0.255 & 0.183 & 0.273 \\
\hline $\mathrm{Ca}$ & 0.000 & 0.003 & - & - & 0.010 \\
\hline $\mathrm{Na}$ & 0.133 & 0.143 & - & 0.107 & 0.180 \\
\hline $\mathrm{K}$ & 1.776 & 1.785 & - & 1.890 & 1.697 \\
\hline $\mathrm{F}$ & - & - & 0.089 & 0.017 & 0.038 \\
\hline $\mathrm{Cl}$ & - & - & 0.002 & - & 0.000 \\
\hline
\end{tabular}

than the values calculated with the thermometer of Williams and Grambling (1990). The difference between values for garnet core and garnet rim (using the same biotite composition) was used as a criterion of secondary importance, resting on the assumption that the difference in calculated temperatures for core and rim, respectively, should not be high. The temperatures calculated with the thermometer of Indares and Martignole (1985) are unrealistically low (by as much as $150^{\circ} \mathrm{C}$ lower) than data obtained following the procedure of Williams and Grambling (1990). The calculated pressure-temperature data are plotted in Fig. 11, arbitrarily with T uncertainty of $50{ }^{\circ} \mathrm{C}$ and $\mathrm{P}$ of $0.15 \mathrm{GPa}$, which are near to a minimal theoretical error following from the character of the thermodynamic data (Williams and Grambling 1990). The true uncertainty in temperature estimate is unknown due to several factors, including the possibility of partial re-equilibration via Grt-Bt ion exchange.

Among samples from the Běstvina Unit, samples 5 and 9 can be used for geobarometric calculations. By using these 
Tab. 8 Chemical composition of tourmaline and dumortierite

\begin{tabular}{|c|c|c|c|c|c|}
\hline $\begin{array}{c}\text { Sample } \\
\text { Mineral } \\
\text { Anal. No. }\end{array}$ & $\begin{array}{c}3 \\
\text { Tour I } \\
\text { 1b }\end{array}$ & $\begin{array}{c}\mathbf{3} \\
\text { Tour II } \\
\text { 23a }\end{array}$ & $\begin{array}{c}4 \\
\text { Tour I } \\
15\end{array}$ & $\begin{array}{c}3 \\
\text { Dumort. } \\
\text { 10b }\end{array}$ & $\begin{array}{c}4 \\
\text { Dumort. } \\
58\end{array}$ \\
\hline $\mathrm{SiO}_{2}$ & 37.15 & 36.78 & 37.04 & 31.79 & 31.51 \\
\hline $\mathrm{TiO}_{2}$ & 0.94 & 0.15 & 1.11 & 0.20 & 0.83 \\
\hline $\mathrm{Al}_{2} \mathrm{O}_{3}$ & 33.67 & 35.18 & 33.59 & 59.31 & 58.72 \\
\hline $\mathrm{B}_{2} \mathrm{O}_{3}{ }^{*}$ & 10.78 & 10.81 & 10.83 & 5.90 & 5.90 \\
\hline $\mathrm{Cr}_{2} \mathrm{O}_{3}$ & 0.01 & 0.00 & 0.01 & 0.00 & 0.00 \\
\hline $\mathrm{V}_{2} \mathrm{O}_{3}$ & 0.03 & 0.01 & 0.02 & 0.00 & 0.03 \\
\hline $\mathrm{FeO}$ & 6.50 & 6.58 & 6.80 & 0.23 & 0.25 \\
\hline $\mathrm{MnO}$ & 0.00 & 0.00 & 0.02 & 0.02 & 0.02 \\
\hline $\mathrm{MgO}$ & 5.93 & 5.59 & 6.18 & 1.20 & 1.02 \\
\hline $\mathrm{CaO}$ & 0.15 & 0.15 & 0.17 & 0.02 & 0.00 \\
\hline $\mathrm{Na}_{2} \mathrm{O}$ & 2.23 & 2.35 & 2.41 & 0.01 & 0.03 \\
\hline $\mathrm{K}_{2} \mathrm{O}$ & 0.07 & 0.03 & 0.06 & 0.02 & 0.01 \\
\hline $\mathrm{P}_{2} \mathrm{O}_{5}$ & 0.00 & 0.00 & 0.08 & 0.07 & 0.00 \\
\hline $\mathrm{ZnO}$ & 0.12 & 0.12 & 0.12 & 0.03 & 0.00 \\
\hline $\mathrm{H}_{2} \mathrm{O}^{*}$ & 3.71 & 3.73 & 3.74 & - & - \\
\hline F & 0.03 & 0.00 & 0.00 & 0.05 & 0.07 \\
\hline $\mathrm{Cl}$ & - & - & 0.01 & 0.00 & 0.01 \\
\hline -F eq. & 0.01 & - & - & 0.02 & 0.03 \\
\hline Total & 101.30 & 101.48 & 102.19 & 98.83 & 98.37 \\
\hline \multicolumn{4}{|c|}{ Number of ions based on $31(\mathrm{O}, \mathrm{OH}, \mathrm{F})$} & \multicolumn{2}{|l|}{$18(\mathrm{O}, \mathrm{OH})$} \\
\hline $\mathrm{Si}$ & 5.987 & 5.914 & 5.942 & 3.000 & 3.000 \\
\hline $\mathrm{Ti}$ & 0.114 & 0.018 & 0.134 & 0.014 & 0.060 \\
\hline $\mathrm{Al}$ & 6.396 & 6.666 & 6.350 & 6.595 & 6.590 \\
\hline $\mathrm{B}^{*}$ & 3.000 & 3.000 & 3.000 & 1.000 & 1.011 \\
\hline $\mathrm{Cr}$ & 0.001 & - & 0.001 & - & - \\
\hline V & 0.004 & 0.001 & 0.003 & - & 0.002 \\
\hline $\mathrm{Fe}^{2+}$ & 0.876 & 0.885 & 0.912 & 0.018 & 0.020 \\
\hline $\mathrm{Mn}$ & - & - & 0.003 & 0.002 & 0.002 \\
\hline Mg & 1.425 & 1.340 & 1.478 & 0.169 & 0.145 \\
\hline $\mathrm{Ca}$ & 0.026 & 0.026 & 0.029 & 0.002 & - \\
\hline $\mathrm{Na}$ & 0.697 & 0.733 & 0.750 & 0.001 & 0.006 \\
\hline $\mathrm{K}$ & 0.014 & 0.006 & 0.012 & 0.001 & 0.001 \\
\hline $\mathrm{P}$ & - & - & - & 0.017 & - \\
\hline $\mathrm{Zn}$ & 0.014 & 0.014 & 0.014 & 0.002 & - \\
\hline Total & 18.554 & 18.603 & 18.628 & 10.821 & 10.837 \\
\hline $\mathrm{F}$ & - & - & - & 0.016 & 0.022 \\
\hline
\end{tabular}

* $-\mathrm{B}_{2} \mathrm{O}_{3}$ in tourmaline and dumortierite and $\mathrm{H}_{2} \mathrm{O}$ in tourmaline calculated from stoichiometry (Grew 1996)

samples we avoid problems with unmixed feldspars (mesoperthite), which is usually the main feldspar in felsic granulites. Owing to its rather sodic whole-rock composition, the sample 5 is dominated by albite. Sample 9 contains some antiperthite, but plagioclase is the most common feldspar.

On the other hand, sample 4 - the polymetamorphic leucosome - contains no mineral assemblage suitable for temperature calculation for the $\mathrm{M}_{2}$ stage: biotite replacing garnet or muscovite I at margins is interpreted as belonging to the $\mathrm{M}_{3}$ assemblage. Consequently, the pressure data for sample 4 are plotted somewhat arbitrarily at $\mathrm{T}=800{ }^{\circ} \mathrm{C}$, with reference to temperature calculated on another migmatite sample from the same Malín Unit (Nahodilová et al. 2006).

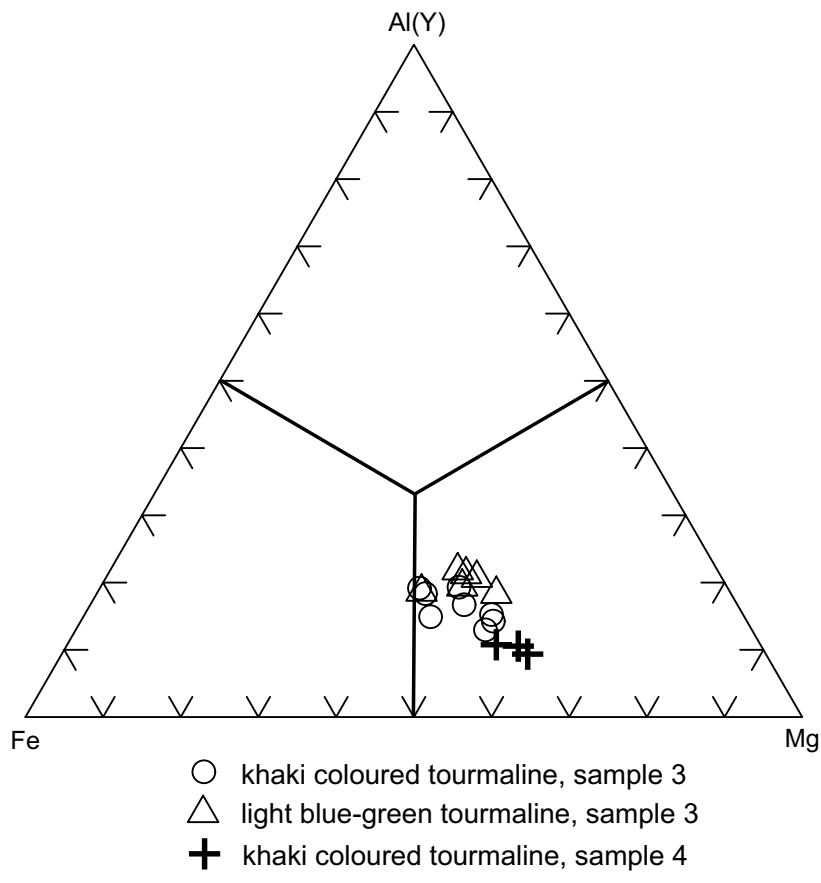

Fig. 10 Tourmaline composition in $\mathrm{Fe}-\mathrm{Mg}-\mathrm{Al}(\mathrm{Y})$ diagram.

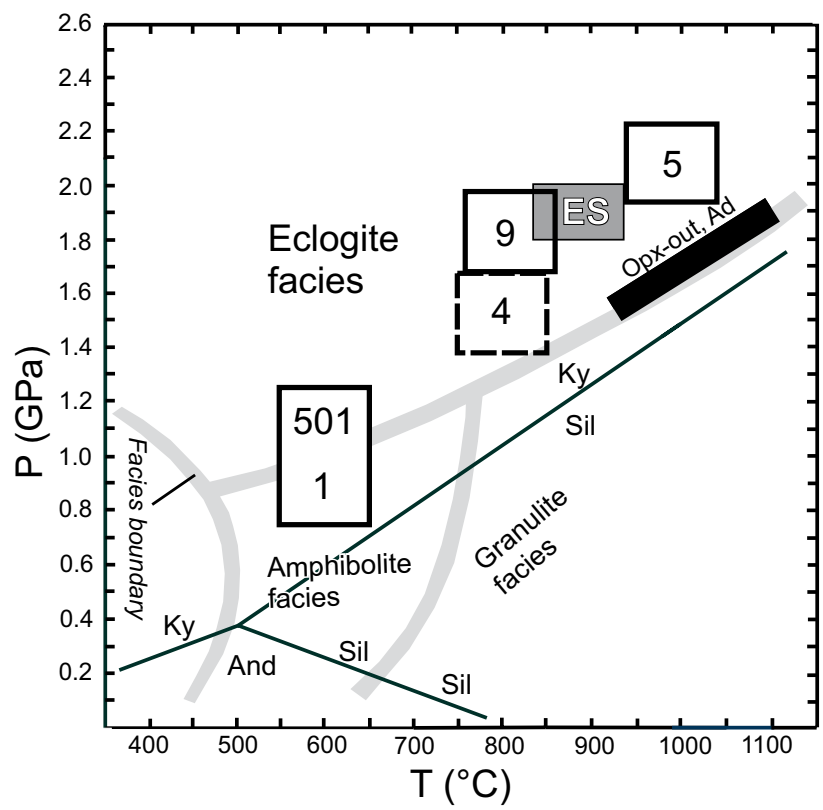

Fig. 11 Calculated P-T equilibration conditions for the granulites (samples 5 and 9, Spačice, Běstvina Unit), the polymetamorphic leucosome from migmatite (sample 4, Malín Unit), and the felsic gneiss (samples 1 and 501, Malín Unit). Data for eclogite of tholeiitic composition from Spačice village (grey rectangle labelled ES), are from Medaris et al. (2006). The Opx-out curve for adamellite composition (bold contour) is from Green and Lambert (1965). Metamorphic facies fields are from Spear (1993). The calculated pressures and temperatures are plotted with arbitrary errors following from thermodynamic data (temperature $\pm 50{ }^{\circ} \mathrm{C}$, pressure $0.15 \mathrm{GPa}$ ). True errors are not defined; see text for explanation. 


\subsection{Data for individual metamorphic events}

Event $M_{r}$. The calculated P-T conditions for albite-Kfeldspar $\mathrm{Bi}-\mathrm{Ky}-\mathrm{Grt}$ granulite, sample 5, correspond to $\mathrm{T}=989-980{ }^{\circ} \mathrm{C}$ (Williams and Grambling 1990) or 933-872 ${ }^{\circ} \mathrm{C}$ (Ferry and Spear 1978), and $\mathrm{P}=1.8-2.1$ GPa (Fig. 11).

Calc-alkali Ky-Grt granulites of granite composition in the Běstvina Unit yielded metamorphic conditions of $\mathrm{T}=840-920{ }^{\circ} \mathrm{C}$ and $\mathrm{P}=1.8-2.2 \mathrm{GPa}$, corresponding to eclogite-facies conditions outside the orthopyroxene stability field (Vrána et al. 2005). The newly obtained information on samples 5 and 6 shows that some albite-Kfeldspar rocks with advanced geochemical fractionation endured the HP/HT eclogite-facies conditions, together with the prevailing granulitic rocks of calc-alkali granite composition in the Běstvina Unit.

Nahodilová et al. (2006) calculated for the HP/HT stage of the Běstvina felsic granulite peak P-T conditions of $831 \pm 53{ }^{\circ} \mathrm{C}$ and $1.65 \pm 0.18 \mathrm{GPa}$, followed by retrogression at $705 \pm 97{ }^{\circ} \mathrm{C}$ and $1.4 \pm 0.2 \mathrm{GPa}$, using the average P-T method (Powell et al. 1998) and different samples. The results suggest retrogression at relatively high pressure in the kyanite stability field.

Event $M_{2}$. The pressure 1.6 GPa calculated for sample 4, leucosome from the Bylanka brook migmatite, is interpreted as relating to the original HP anatectic mineral assemblage. The fact that the leucosome in sample 4 exhibits effects of superimposed penetrative shearing and partial amphibolitefacies recrystallization with newly formed fine-grained muscovite, comparable to $D_{3} / M_{3}$ in felsic gneiss samples 1,2 and 501, proves that the high-pressure migmatitic assemblage in sample 4 pre-dated the $\mathrm{D}_{3} / \mathrm{M}_{3}$ event.

Nahodilová et al. (2006) estimated the maximum $\mathrm{P}-\mathrm{T}$ conditions using the Ky-Grt-Ms-Kfs-Ab-Qtz assemblage in the Malín and Běstvina kyanite-bearing migmatites $\left(\mathrm{M}_{2}\right.$ ?) at $875 \pm 95{ }^{\circ} \mathrm{C}$ and $1.56 \pm 0.14 \mathrm{GPa}$ using the average P-T method (Powell et al. 1998). The data for MP/LT retrogression calculated by Nahodilová et al. (2006) from the matrix biotite, garnet rims and the recrystallized grains of plagioclase, $\mathrm{K}$-feldspar and quartz yielded P-T conditions of $712 \pm 39{ }^{\circ} \mathrm{C}$ and $1.06 \pm 0.18 \mathrm{GPa}$, which could be compared with the event $M_{3}$. The values calculated for the $M_{2}$ event in HP migmatites of the Malín Unit can be compared with P-T data obtained for a migmatitic gneiss from the Běstvina Unit ( $\mathrm{P}=1.4 \mathrm{GPa}, \mathrm{T}=660^{\circ} \mathrm{C}$ : Vrána et al. 2005).

Event $M_{3}$. The $\mathrm{Ky}-\mathrm{Grt}-\mathrm{Ms}-\mathrm{Kfs}-\mathrm{Ab}-\mathrm{Qtz}$ assemblage in the felsic gneiss samples 1,2 and in the matrix of sample 501 (Bohouňovice and Suchdol) yield an $\mathrm{M}_{3}$ pressure estimate of 0.9 to $1.2 \mathrm{GPa}$ using the GASP barometry according to Koziol and Newton (1988). Temperature estimate in sample 501, based on the garnetbiotite thermometer of Williams and Grambling (1990) is
$730{ }^{\circ} \mathrm{C}$. This rather high value, given the abundance of muscovite, prompted checking muscovite stability field in this sample with the Thermocalc 3.30 (Powell et al. 1998) pseudosection. Muscovite stability field in the rock of given composition extends up to $c .750{ }^{\circ} \mathrm{C}$ at pressure of $1.1 \mathrm{GPa}$. However, there are some doubts concerning equilibrium between rare biotite and matrix garnet. The equilibration conditions correspond to amphibolitefacies at increased pressure. During the $\mathrm{M}_{3}$ event, newly formed, fine-grained, syn-foliation muscovite and kyanite crystallized in the country rocks involved in the regional shearing and re-equilibration.

\subsection{Comparison of felsic KHC gneisses with felsic granulites from the Běstvina Unit}

The kyanite-garnet felsic gneisses from the Malín Unit (KHC) (samples 1 and 2) show geochemical characteristics comparable to unmetamorphosed, highly evolved albite leucogranites worldwide. New trace-element data for samples 5 and 6 (Tab. 3) from the Běstvina Unit, resembling somewhat those for samples 1 and 2 from the Malín Unit, show several geochemical features indicating an evolved, probably magmatic protolith. On the other hand, the albite granulites (samples 5 and 6) differ from the calc-alkali leucogranitic-granitic granulites dominating in the Běstvina Unit, (Fiala et al. 1987; Vrána et al. 2005). These felsic calc-alkali granulites, represented by samples 7 and 8, have equilibrated under eclogite-facies conditions (Vrána et al. 2005). Samples 5 and 6 exhibit relatively high $\mathrm{Rb} / \mathrm{Sr}$ and $\mathrm{Rb} / \mathrm{Ba}$ ratios (Fig. 4b), low $\mathrm{Zr}$ and $\mathrm{Y}$ contents (Fig. 4a) and low total REE contents. However, the overall shapes of the REE patterns are more similar to those of the calc-alkali felsic granulites (sample 8) and the metasedimentary granulite rich in Grt and Ky (sample 9) (Fig. 5), rather than to the felsic gneisses from the Malín Unit. The compositional differences between garnets from albite-K-feldspar felsic gneisses from the $\mathrm{KHC}$ and the samples of HT/HP granulites from the Běstvina Unit can be seen in Fig. 8. The high contents of Prp and Grs in garnet from the Běstvina granulites greatly exceed the contents in garnet from the $\mathrm{KHC}$ rocks and indicate notably higher P-T conditions for the Běstvina granulites (Fig. 11).

\section{Discussion}

\subsection{Geochemical and mineralogical implications for the protolith of felsic gneisses}

There are several whole-rock compositional features indicating that the protoliths of the felsic gneisses from 
the Malín Unit were highly fractionated magmatic rocks, namely: high $\mathrm{Rb} / \mathrm{Sr}$ and $\mathrm{Rb} / \mathrm{Ba}$ ratios (Fig. $4 \mathrm{~b}$ ), low $\mathrm{Zr} / \mathrm{Hf}$ ratios ( 14), low $\mathrm{Zr}$ and $\mathrm{Y}$ contents (Fig. 4a), low FeOt/ $\mathrm{MnO}$ ratios ( 14), and low total REE contents (10-14 ppm) (Tab. 1). Compared to these extreme values, ordinary calcalkali granitic rocks have $\mathrm{Zr} / \mathrm{Hf}$ ratios near $30, \mathrm{FeOt} / \mathrm{MnO}$ ratios near 50 and total REE contents near 100. Concentrations of certain elements and element/element ratios, such as low FeOt/MnO, $\mathrm{Zr} / \mathrm{Hf}$ (Tab. 1), $\mathrm{Zr}$ and Y (Fig. 4a), high $\mathrm{Rb} / \mathrm{Sr}$ and $\mathrm{Rb} / \mathrm{Ba}$ ratios (Fig. $4 \mathrm{~b}$ ), together with low total REE contents prove conclusively that the felsic gneisses were derived by metamorphism of leucogranitic rocks crystallized from highly evolved magmas. The geochemically evolved character of granites is usually shown by high contents of rare elements ( $\mathrm{Rb}, \mathrm{Li}, \mathrm{Cs}, \mathrm{Sn}, \mathrm{Nb}, \mathrm{Ta})$ and strongly depleted REE (Breiter and Scharbert 1998; Černý and Ercit 2005). In contrast, in felsic gneisses the evolved character is manifested by element/element ratios and low to very low contents of rare elements. Chondrite-normalized REE patterns (Fig. 5) show that samples 1 and 2 have only a weak negative Eu anomaly. The protolith for sample 3 from Vysoká is not identified. However, it is different from the protolith for samples 1 and 2 as indicated by differences in $\mathrm{FeOt} / \mathrm{MgO}$ and $\mathrm{FeOt} / \mathrm{MnO}$ values, REE characteristics (Fig. 5) and minor element data. The granulite samples 7 and 8 from the Běstvina Unit come near to values similar to ordinary calc-alkali granite.

In peraluminous granites the $\mathrm{Zr} / \mathrm{Hf}$ ratios tend to be close to the chondritic value ( $\sim 36)$ (Dostal and Chatterjee 2000). According to Linnen and Keppler (2002) partition coefficients of $\mathrm{Zr}$ and $\mathrm{Hf}$ between zircon and peraluminous polymerized melts $\mathrm{D}^{\mathrm{Hf}} / \mathrm{D}^{\mathrm{Zr}}$ for zircon is 0.5 to 0.2 . Consequently, zircon fractionation will strongly decrease $\mathrm{Zr} / \mathrm{Hf}$ in some granites. As $\mathrm{Mn}$ is geochemically similar to $\mathrm{Fe}$, the planetary $\mathrm{Fe} / \mathrm{Mn}$ ratio is approximately constant, corresponding to $\sim 54-58$ in various MORB basalts (Qin and Humayun 2008). Thus the Fe/Mn ratio near 50 dominates in majority of crustal rocks.

In addition to these data, strong evidence in favour of a garnetiferous leucogranitic protolith for felsic gneisses is provided by large, relict almandine- and spessartine-rich garnet porphyroclasts (2 to $3 \mathrm{~cm}$ in diameter) with $\mathrm{P}_{2} \mathrm{O}_{5}$ contents in the range of 0.1 to 0.5 wt. \% (Tab. 7, Figs $6 \mathrm{a}-\mathrm{b})$. Garnet porphyroclasts contain approx. 50 vol. \% of intergrown quartz, which escaped mylonitic deformation. The garnet-quartz intergrowth pattern is analogous to that observed in some unmetamorphosed Variscan garnetiferous leucogranites (Fig. 7) (Breiter et al. 2003; Vrána 2005; René and Stelling 2007). As indicated by comparison of the whole-rock analyses 1 and 2, an average for five whole-rock analyses published by Fiala (1992), and our results of microscopic and microprobe study, the felsic gneisses are characterised by minimal variation in composition.
During a superimposed event of pervasive shearing, mylonitization, fabric flattening and moderate-temperature, but high-pressure (MT/HP) re-equilibration $\left(\mathrm{D}_{3}\right.$, $\mathrm{M}_{3}$ ), the leucogranitic bodies were structurally transposed (refoliated) together with the surrounding rocks of the Malín Unit. Primary quartz mosaic was transposed to quartz ribbons or elongated lenticular aggregates. Variation in the $\mathrm{Ky} / \mathrm{Ms}$ ratio in laminae across the foliation can be interpreted as resulting from variable hydrous fluid activity, since any indications of replacement relations between Ms and Ky are absent. Although kyanite-garnetmuscovite felsic gneisses from Bohouňovice and Suchdol were sometimes designated as "leptynite" (Fiala et al. 1982; Fiala 1992), or considered to be rocks with some relation to granulites, it is obvious that such relationship is based only on a macroscopic resemblance, whereby abundant small garnets are set in a fine-grained felsic matrix. However, the metamorphic record of the gneisses corresponds solely to amphibolite-facies conditions.

\subsection{Possible ultrahigh-pressure history of leucosome from migmatite, indicated by the high sodium content in garnet}

Large syn-migmatization garnets (1 to $4 \mathrm{~mm}$ in diameter) contain 0.05 to $0.10 \mathrm{wt}$. $\% \mathrm{Na}_{2} \mathrm{O}$, accompanied by somewhat elevated phosphorus (Tab. 4). Such high sodium values are indicative of ultrahigh-pressure (UHP) conditions, as described from Dabie Shan and Dabie Sulu UHP terranes in China (Enami et al. 1995; Carswell et al. 2000) and for diamond-bearing detrital assemblages in the Bingara Area, Eastern Australia (Barron et al. 2005). According to Barron et al. (2005), high-sodium, AlmSps-rich garnets are interpreted as being derived from deeply subducted tonalitic and granitic gneisses, although some samples with increased Prp and Grs components also occur. The low grossular content reflects a low-Ca nature of the granitic gneisses. There is some uncertainty concerning the meaning of the calculated pressure value of $1.6 \mathrm{GPa}$ for sample 4 , which is definitely far beyond the UHP realm. Admittedly, there is a problem concerning the equilibrium between the large garnet grains and the matrix albite. Given the limited compositional data, it is preferable to consider the increased sodium contents in sample 4 as a probable or potential indication of a UHP event in the history of the sample, which could be confirmed only by a detailed study.

\subsection{Crystallization of borosilicates}

As tourmaline and dumortierite in samples 3 and 4 occur in different parts of thin sections, the mutual temporal relations of these minerals are difficult to assess. 
However, both minerals are post- $\mathrm{D}_{3}$ and may be closely related in time.

Regional information shows that tourmaline has been often observed in the muscovite-biotite gneisses and schists in the Malín Unit. As these rocks, in part migmatitic, predominate in the area, it is probable that alteration of tourmaline during $\mathrm{M}_{3}$ supplied boron needed for crystallization of minor late borosilicates in the studied felsic gneisses. In general, in the KHC and the Svratka Unit, tourmaline is present in paragneisses with tourmalinite layers (Čopjaková et al. this volume), in some quartz-feldspar leucosomes and in hydrothermal quartz-tourmaline veinlets. There is no evidence for the presence of primary magmatic tourmaline in the protolith of the felsic gneisses (samples 1 to 3). However, primary tourmaline, if present formerly in the rock, would represent an alternative source for the late dravite-schorl and dumortierite growth.

The high-grade felsic kyanite-garnet granulites in the Běstvina Unit are completely free of borosilicates. One occurrence of dumortierite-bearing pegmatite in the Běstvina granulites, emplaced after culmination of the granulite HP/HT conditions, has been described by Cempírek and Novák (2006). The regional coincidence in occurrences of dumortierite pegmatites (Fiala 1954; Losert 1956a; Cempírek and Novák 2006), with numerous localities of accessory dumortierite in polymetamorphic gneisses and migmatites of the Malín Unit (Fig. 2), may indicate that dumortierite pegmatites were emplaced at a late stage related to the $\mathrm{M}_{3}$ event. This is a preliminary suggestion requiring additional evidence.

\subsection{Correlation of the Kutná Hora-Svratka Superunit with the Orlice-Sněžník (Orlice-Klodzko) Unit (OSU) at the Czech-Polish border}

Several aspects indicate that the Kutná Hora-Svratka Superunit (Fig. 1) can probably be correlated with the Orlice-Sněžník Unit (OSU) further northeast, at the Czech-Polish border (Verner et al. this volume). Important points for this correlation of the Kutná HoraSvratka Superunit with the OSU are the following: a) dating of garnet clinopyroxenites and associated pyrope lherzolite from Bečváry at approximately $377 \pm 20 \mathrm{Ma}$ (Brueckner et al. 1991) and indication of prolonged annealing of pyrope lherzolites in $\mathrm{KHC}$ following from study of mineral inclusions in pyrope (Vrána 2008); b) geochemical correlation of (Cambro-Ordovician) Svratka metagranite/orthogneiss with orthogneisses in the Orlické hory Mts. indicates a close similarity (Buriánek et al. this volume); c) comparison of the whole-rock geochemistry of mica schists and migmatites of the Svratka Unit with paragneisses and migmatites of the adjacent part of the
Moldanubian Zone (Strážek Unit) shows that the former were derived from geochemically more evolved and differentiated source (unpublished data). The main obstacle to closer correlation is the paucity of geochronological data on KHC rocks.

\subsection{Correlation of the Kutná Hora-Svratka Superunit with the Moldanubian Zone in terms of metamorphism}

The main difference between the Moldanubian Zone and $\mathrm{KHC}$ is in that in latter unit decompression proceeded dominantly in the kyanite field whereas, in the Moldanubian rocks, decompression was one of a prominent, nearly isothermal uplift with widespread neoformation of sillimanite, replacement of kyanite by hercynitic spinel and/or low-Ca garnet, and crystallization of cordierite (Owen and Dostal 1996; Tajčmanová et al. 2006). These relations suggest that the KHC and the Moldanubian complex evolved separately for much of their Variscan tectonometamorphic history. The repetitive high-pressure record manifested in the $\mathrm{KHC}$ by $\mathrm{M}_{1}$ (eclogite-facies granulites, $\mathrm{P} \sim 2.0 \mathrm{GPa}$ ), $\mathrm{M}_{2}$ migmatites with Ky-bearing leucosome (eclogite-facies, $1.6 \mathrm{GPa}$ ), $\mathrm{M}_{3}$ recrystallization related to penetrative shearing (HP amphibolite-facies, $1.1 \mathrm{GPa}$ ) represents a unique record at the present stage of knowledge of the Bohemian Massif. Clarification of the time and space relations between $M_{1}$ and $M_{2}$ requires additional data, as it is concerned with the allochthonous position of HP/HT Běstvina Unit granulites in the KHC. It is probable that the $M_{1}$ and $M_{2}$ events corresponded to Palaeo-Variscan processes (older than $340 \mathrm{Ma}$ ) and the $\mathrm{M}_{3}$ event to Neo-Variscan processes ( $340 \mathrm{Ma}$, coeval with the exhumation of the Moldanubian Zone).

\section{Conclusions}

In the Kutná Hora Complex, there are several types of albite-K-feldspar kyanite-garnet felsic gneisses, polymetamorphic migmatites and granulites. The felsic gneisses from Bohouňovice and Suchdol (Malín Unit, samples 1 and 2) formed by a late penetrative shearing and $\mathrm{M}_{3}$ metamorphism of a primary, highly evolved, garnetiferous leucogranite. The protolith for sample 3 from Vysoká (Malín Unit) remains uncertain, though it was also a highly fractionated albitic rock. A leucosome from a polymetamorphic migmatite (sample 4, Malín Unit) exhibits effects of $\mathrm{D}_{3}$ deformation and partial modification by superimposed $\mathrm{M}_{3}$ metamorphism, but its garnet and coarse kyanite are interpreted as having been formed during the $\mathrm{M}_{2}$ high-pressure migmatization event. Felsic HP/HT albite-K-feldspar granulites from the Běstvina Unit, samples 5 and 6 , exhibit only the 
near-peak metamorphic mineral assemblage. Geochemical data suggest a highly evolved magmatic protolith for this rock, but essentially different from that for felsic gneisses in the Malín Unit.

The published scheme of deformation events $\left(D_{1}\right.$ to $\left.D_{3}\right)$ and polymetamorphism $\left(M_{1}\right.$ to $\left.M_{3}\right)$ proved to be applicable for description of the record registered in the studied sample set. This scheme of events is very different from the record observed in the regionally neighbouring rocks of the Moldanubian Zone. The main difference is in that in KHC decompression proceeded dominantly in the kyanite field whereas, in the Moldanubian rocks, decompression was one of a prominent, nearly isothermal uplift with widespread neoformation of sillimanite, replacement of kyanite by hercynitic spinel and/or low-Ca garnet, and crystallization of cordierite.

Textural and compositional data of metamorphic dravite-schorl tourmaline and dumortierite in the felsic gneisses may be used for interpretation of the probable emplacement time of dumortierite pegmatites described from the Kutná Hora region in the literature.

Acknowledgements We studied the felsic gneisses within the framework of the project: "Investigation of lithologically contrasting rocks in the crystalline units at the NE margin of the Moldanubian Zone" headed by J. Pertoldová. We would like to thank P. Škoda, Faculty of Science, Brno, for microprobe analyses, K. Kullerud and R. Kryza for critical comments and constructive reviews of the manuscript. Microprobe analyses of minerals were recalculated to the numbers of atoms using worksheets presented by A. Tindle at http://www.open. ac.uk/earth-research/tindle/AGTWebPages/AGTSoft.html. Data handling, recalculation and plotting were performed using the R language package GCDkit (Janoušek et al. 2006b).

Electronic supplementary material. The GPS coordinates of the studied samples, and the tables of whole-rock geochemical data (Tabs 2-3) are available online at the Journal web site (http://dx.doi.org/10.3190/jgeosci.045).

\section{References}

Alcock J (1996) Effect of grossular on garnet-biotite, $\mathrm{Fe}-\mathrm{Mg}$ exchange reactions: evidence from garnet with mixed growth and diffusion zoning. Contrib Mineral Petrol 124: 209-215

Barron BJ, Barron LM, Duncan G (2005) Eclogitic and ultrahigh-pressure crustal garnets and their relationship to Phanerozoic subduction diamonds, Bingara Area, New England Fold Belt, Eastern Australia. Econ Geol 100: $1565-1582$
Boynton WV (1984) Cosmochemistry of the rare earth elements: meteorite studies. In: HeNDERSON P (ed) Rare Earth Element Geochemistry. Elsevier, Amsterdam, pp 63-114

Breiter K, Scharbert S (1998) Latest intrusions of the Eisgarn Pluton (South Bohemia-Northern Waldviertel). Jb Geol B-A 141: 25-37

Breiter K, Beran A, Buriánek D, Cempírek J, Dutrow B, Henry D, Novák M, Povondra P, Raimbault L (2003) Přibyslavice near Čáslav, locality No. 10. In: NovÁK M (ed) Field Trip Guidebook, International Symposium on Light Elements in Rock-forming Minerals. Masaryk University, Brno, pp 77-90

Brueckner HK, Medaris LG, Bakun-Czubarow N (1991) $\mathrm{Nd}$ and $\mathrm{Sr}$ age and isotope patterns from Variscan eclogites of the eastern Bohemian Massif. Neu Jb Mineral, Abh 163: 169-196

Buriánek D, Verner K, Hanžl P, Krumlová H (2009) Ordovician metagranites and migmatites of the Svratka and Orlice-Sněžník Units, northeastern Bohemian Massif. J Geosci 54: 181-200

Carswell DA, Wilson RN, Zhai M (2000) Metamorphic evolution, mineral chemistry and thermobarometry of schists and orthogneisses hosting ultra-high pressure eclogites in the Dabieshan of Central China. Lithos 52: 121-155

Cempírek J, Novák M (2006) Mineralogy of dumortieritebearing pegmatites at Starkoč and Běstvina, Kutná Hora Crystalline Complex. J Czech Geol Soc 51: 259-270

ČERNÝ P, ERCIT TS (2005) The classification of granitic pegmatites revisited. Canad Mineral 43: 1601-1622

Čopjaková R, Buriánek D, ŠKoda R, HouZar S (2009) Tourmalinites in the metamorphic complex of the Svratka Unit (Bohemian Massif): a study of compositional growth of tourmaline and genetic relations. J Geosci 54: 221-243

Dostal J, Chatterjee AK (2000) Contrasting behaviour of $\mathrm{Nb} / \mathrm{Ta}$ and $\mathrm{Zr} / \mathrm{Hf}$ ratios in a peraluminous granitic pluton (Nova Scotia, Canada). Chem Geol 163: 207-218

Enami M, Cong B, Yoshida T, Kawabe I (1995) A mechanism for $\mathrm{Na}$ incorporation in garnet: An example from garnet in orthogneiss from the Dabie Sulu terrane, eastern China. Amer Miner 40: 475-482

FARYAD SW (2009) The Kutná Hora Complex (Moldanubian zone, Bohemian Massif): a composite of crustal and mantle rocks subducted to HP/UHP conditions. Lithos 109: 193-208

FERRY JM, SPEAR FS (1978) Experimental calibration of the partitioning of $\mathrm{Fe}$ and $\mathrm{Mg}$ between biotite and garnet. Contrib Mineral Petrol 66: 113-117

Fiala F (1954) Dumortierite from Miskovice. Sbor Nár Mus Prague 10B, 2: 3-38 (In Czech)

Fiala J (1992) Bořetice, granulitic layer in paragneiss of Malín Formation, Stop 17. In: Fiala J, FišERA M, 
Jelínek E, SlabÝ J, VRána S (eds) High-Pressure Granulites - Lower Crustal Metamorphism, Excursion guide. Czech Geological Survey, Prague, pp 50-52

Fiala J, Lang M, Obrda J, Pivec E, Ulrych J (1982) Petrology of some garnet-kyanite-K-feldspar leptynites of the Czech Moldanubicum (Czechoslovakia). Rozpr Čs Akad Věd, ř Mat Př́r Věd 92: 1-85

Fiala J, MatěJovská O, VaňKová V (1987) Moldanubian granulites and related rocks: petrology, geochemistry and radioactivity. Rozpr Čs Akad věd, ř Mat Př́r Věd 97: 1-102

FIŠERA M (1977) Geology and petrology of the Kutná Hora Unit west of Kolín. Czech Geological Survey Research Papers 16: 19-31 (in Czech)

GREEN DH, LAMBERT IB (1965) Experimental crystallisation of anhydrous granite at high pressures and temperatures. J Geophys Res 70: 5259-5268

GREW ES (1996) Borosilicates and boron in rock-forming minerals in metamorphic environments. In: GREw ES, AnOvitz LM (eds) Boron, Mineralogy, Petrology and Geochemistry. Mineralogical Society of America Reviews in Mineralogy 33: 387-502

Indares A, Martignole J (1985) Biotite-garnet geothermometry in the granulite facies: the influence of Ti and $\mathrm{Al}$ in biotite. Amer Miner 70: 272-278

JANOUŠEK V, Finger F, Roberts MP, FrÝdA J, Pin C, DolejŠ D (2004) Deciphering petrogenesis of deeply buried granites: whole-rock geochemical constraints on the origin of largely undepleted felsic granulites from the Moldanubian Zone of the Bohemian Massif. Trans Roy Soc Edinb, Earth Sci 95: 141-159

Janoušek V, Gerdes A, VRána S, Finger F, Erban V, Friedl G, BRAithwaite CJR (2006a) Low-pressure granulites of the Lišov Massif, southern Bohemia: Viséan metamorphism of Late Devonian plutonic arc rocks. J Petrol 47: 705-744

JANOUŠEK V, FARROW CM, ERBAN V (2006b) Interpretation of whole-rock geochemical data in igneous geochemistry: introducing Geochemical Data Toolkit (GCDkit). J Petrol 47: 1255-1259

Janoušek V, Krenn E, Finger F, Míková J, FrÝdA J (2007) Hyperpotassic granulites from the Blanský les Massif (Moldanubian Zone, Bohemian Massif) revisited. J Geosci 52: 73-112

KotKovÁ J (2007) High-pressure granulites of the Bohemian Massif: recent advances and open questions. J Geosci 52: $45-71$

Koziol AM, Newton RC (1988) Redetermination of the anorthite breakdown reaction and improvement of the plagioclase-garnet- $\mathrm{Al}_{2} \mathrm{SiO}_{5}$ - quartz geobarometer. Amer Miner 76: 216-223

KRETZ R (1983) Symbols for rock-forming minerals. Amer Miner 68: 277-279

Le Maitre RW (ed.) (1989) A Classification of Igneous
Rocks and Glossary of Terms. Blackwell Scientific Publications, Oxford, pp 1-193

LinNen RL, KePPLER H (2002) Melt composition control of $\mathrm{Zr} / \mathrm{Hf}$ fractionation in magmatic processes. Geochim Cosmochim Acta 66: 3293-3301

Losert J (1956a) Dumortierites from the migmatites and pegmatites in the vicinity of Kutná Hora. Rozpr Čs Akad Věd, ř Mat Př́r Věd 66: 1-44 (in Czech)

LOSERT J (1956b) Report on detailed geological mapping in the northern part of the Kutná Hora ore district. Zpr geol výzk v Roce 1955: 99-101 (in Czech)

LOSERT J (1967) Contribution to the problem of the pre-Assyntian tectogenesis and metamorphism in the Moldanubicum of the Bohemian Massif. Krystalinikum 5: 61-84

Medaris LG Jr, GHent ED, WANG HF, Fournell JH, Jelínek E (2006) The Spačice eclogite: constraints on the P-T-t history of the Gföhl granulite terrane, Moldanubian Zone, Bohemian Massif. Mineral Petrol 86: 203-220

Nahodilová R, Faryad SW, Pertoldová J, Konopásek J, ŠTĚDRÁ V (2005) HP melting and its relationship to the granulite facies metamorphism - an example of the "Gföhl nappe" in the Kutná Hora Crystalline Complex. Geolines 19: 86-87

Nahodilová R, Faryad S, Pertoldová J, Konopásek J, ŠTĚDRÁ V (2006) The different metamorphic evolution of HP rocks of the Gföhl Unit in Kutná Hora Crystalline Complex against in Moldanubian Zone in Austria. Geolines 20: 98-99

O'BRIEN PJ, RÖTZLER J (2003) High-pressure granulites: formation, recovery of peak conditions and implications for tectonics. J Metamorph Geol 21: 3-20

Owen JV, Dostal J (1996) Prograde metamorphism and decompression of the Gföhl gneiss, Czech Republic. Lithos 38: 259-270

Powell R, Holland T, Worley B (1998) Calculating phase diagrams involving solid solutions via non-linear equations, with examples using THERMOCALC. J Metamorph Geol 16: 577-588

Quin L, Humayun M (2008) The Fe/Mn ratio in MORB and OIB determined by ICP-MS. Geochim Cosmochim Acta 72: 1660-1677

Reche J, Martinez FJ (1996) GPT: an Excel spreadsheet for thermobarometric calculations in metapelitic rocks. Comput and Geosci 22: 775-784

René M, Stelling J (2007) Garnet-bearing granite from the Třebíč Pluton, Bohemian Massif (Czech Republic). Mineral Petrol 91: 55-69

SElway JB, NovÁK M (1997) Experimental conditions, normalization procedures and used nomenclature for tourmaline. Novák M, Selway JB (eds) Symposium Tourmaline 1997, Field Trip Guidebook, Nové Město, pp 19-21

SPEAR FS (1993) Metamorphic Phase Equilibria and Pressure-Temperature-Time Paths. Mineralogical Society of America Monograph, pp 1-799 
SyneK J, OliveriovÁ D (1993) Terrane character of the northeastern margin of the Moldanubian Zone: the Kutná Hora Crystalline Complex, Bohemian Massif. Geol Rundsch 82: 566-582

Štědrá V, Č́á P, Čech S, Dosbaba M, DuŠek K, Holásek O, Hradecká L, Kadlecová R, Mašek D, Ondovčin T, Rejchrt M, Skácelová D, Skácelová Z, Švábenická L, VodrÁŽKa R (2009) Geological map 1 : 25000 of the Czech Republic with explanations, sheet 13-324 Kutná Hora. Czech Geological Survey, Prague

Tajčmanová L, Konopásek J, Schulmann K (2006) Thermal evolution of the orogenic lower crust during exhumation within a thickened Moldanubian root of the Variscan belt of Central Europe. J Metamorph Geol 24: 119-134

Verner K, Buriánek D, Vrána S, Vondrovic L, Pertoldová J, HANŽL P, NAHOdilová R, P (2009) Tectonometamorphic features of geological units along the northern periphery of the Moldanubian Zone (Bohemian Massif). J Geosci 54: 87-100

VRÁNA S (1989) Perpotassic granulites from southern Bohemia, a new rock type derived from partial melting of crustal rocks under upper mantle conditions. Contrib Mineral Petrol 103: 510-522

VRÁNA S (2005) Almandine-spessartine garnet from Zajíčkov near Pelhřimov, Czech Republic. Bull mineralpetrolog Odd Nár Muz (Praha) 13: 232-233 (In Czech) VRÁNA S (2008) Mineral inclusions in pyrope from garnet peridotites, Kolín area, central Czech Republic. J Geosci 53: $17-30$

VRÁnA S, ŠTĚDRÁ V, FišERA M (2005) Petrology and geochemistry of the Běstvina granulite body metamorphosed at eclogite facies conditions, Bohemian Massif. J Czech Geol Soc 50: 95-106

Williams ML, Grambling JA(1990) Manganese, ferric iron, and the equilibrium between garnet and biotite. Amer Miner 75: 886-908 